\title{
DE AFDEELING DOESSONLANDEN
}

(Zuider- en Ooster-afdeeling van Borneo).

DOOR

H. E. D. ENGELHARD.

Omstreeks 1870 werd door de Regeering aan de ambtenaren op de Buitenbezittingen eene vragenreeks voorgelegd betreffende de rechten der bevolking op de onbebouwde gronden in de Gouvernementslanden. De afdeeling Doessonlanden was toen nog nagenoeg onbekend, en de politieke toestanden (men denke slechts aan de onlusten, verwekt door Demang Mas Wangkang) lieten zeer veel te wenschen over. Geen wonder dus, dat al wat destijds omtrent genoemde afdeeling kon worden medegedeeld, weinig waarde heeft ${ }^{1}$, en dat het voor mij, die vier jaren lang aan het hoofd dier afdeeling stond en daardoor gelegenheid had veel te doorgronden wat mijnen voorgangers onbekend moest blijven, eene dankbare taak was het vroeger gewenscht onderzoek weder op te vatten.

Niet alleen uit een politiek of wetenschappelijk oogpunt moest dit nuttig zijn. Nu kapitaal en ondernemingsgeest hunne blikken naar de Doessonlanden richtten, zoowel voor den land-als voor den mijnbouw, was het noodig, de juiste verhoudingen te kennen ter voorlichting van de ondernemers, die daarvan blijkens vele aanvragen wel allerminst op de hoogte waren. Maar al te dikwijls gingen zij uit van de stelling, dat Maleiers en Dajaks geenerlei rechten op hunne gronden konden doen gelden, dat het Gouvernement over deze de vrije beschikking had; de nieuwste kaarten, vervaardigd naar de door wijlen den controleur W. E. M. S. Aernout verzamelde gegevens waren hun onbekend. . . .

1 Zie Résumé der van de verschillende besturende ambtenaren in de Residentie Zuider- en Ooster-afdeeling van Borneo ontvangen antwoorden op de verzameling van vragen, de regten betreffende welke in de onder direkt Gouvernementsgezag staande landen dier residentie door de bevolking op de onbebouwde gronden worden uitgeoefend. Batavia, ter Landsdrukkerij 1876. 
Wat die kaarten betreft, zoolang de Zuider- en Ooster afdeeling van Borneo nog niet topographisch is opgenomen, zullen ook daaraan nog wel fouten kleven, al zijn zij m. i. voor de practijk vrij voldoende.

Doch nu ter zake. Mij eenigszins houdende aan de volgorde, in de bovenbedoelde vragenreeks aangegeven, zal ik in de eerste plaats bespreken: in welke soorten de onbebouwde gronden kunnen worden onderscheiden, en welke benamingen d a a rbij voorkomen.

De onbebouwde gronden worden onderscheiden in de navolgende :

$\mathrm{Himba}$ (Mal. rimba) in de districten Beneden- en Oost-Doesson Katokan en in het distrikt Mengkatib Parak kajoe lakaoe geheeten. Dit zijn oude boschgronden, oerwouden.

Baling - in de onderafdeeling Boentok Lasi geheeten, zijn jonge boschgronden, onderscheiden in baling toew a en baling moeda naar den ouderdom van het daarop staande hout.

Bahoe of verlaten ladanggronden, welke tot den natuurstaat beginnen te vervallen. Zij kunnen dus behoord hebben zoowel tot de himba als tot de baling.

Ook gras- en alang-alangvelden worden in de distrikten Bovenen Midden-Doesson zoo genoemd, maar in de onderafdeeling Boentok ${ }^{1}$ heeten zij Padang. Zijn dergelijke gronden eerst sedert ongeveer acht tot tien jaren verlaten, zoodat zich daarop hoog struikgewas heeft ontwikkeld, dan noemt men ze bloekar.

Loewaoe - in het distrikt Mengkatib Gahagas — zijn moerasgronden, begroeid met oerwoud en nagenoeg het geheele jaar onder water staande. Zij worden aangetroffen, behalve in het geheele evengenoemde distrikt, nog in het zuidelijke en westelijke gedeelte van Oost-Doesson.

Taijap - in de distrikten Beneden en Oost-Doesson Daratan - zijn moerasgronden, nu eens droog vallende, dan weder onder water staande, naargelang van de weersgesteldheid. Dergelijke gronden vindt men overal in de geheele afdeeling, maar zij zijn nooit van eenige noemenswaardige uitgestrektheid. Het komt mij voor, dat de meeste dezer gronden gemakkelijk te draineeren zouden zijn.

1 Kortheidshalve wordt deze benaming hier en verder gebruikt voor de „onderafdeelingen Beneden- en Oost Doesson en Mengkatib", waarvan Boentok de hoofdplaats is. 
Pamatang zijn hooge gronden, welke nooit onder water staan.

Balanak - in de distrikten Beneden- en Oost-Doesson Koempai en in het distrikt Mengkatib Adjakan — zijn aangeslibte gronden. In Boven- en Midden-Doesson vindt men ze niet.

Goesoeng zijn zandgronden, ten eenenmale onvruchtbaar en meest langs de rivieroevers gelegen. In het distrikt Mengkatib komen zij niet voor; in de distrikten Beneden- en Oost-Doessan heeten zij Djoemoeng.

Djaoek - in de beide evengenoemde distrikten Djanah zijn zure gronden, niet voorkomende in het distrikt Mengkatib, bestaande uit een dunne laag rottende blâren en daaronder zeer fijn, wit vochtig zand. Deze lagen zijn hoogstens een d.M. dik en strekken zich golvend soms over eene groote uitgestrektheid onder den bodem uit, soms aan de oppervlakte komende, soms ook ongeveer een M. diep daaronder blijvende. Duidelijk is dit bijv. te zien te Mardoejoeng, distrikt Oost-Doesson. Dergelijke gronden worden geacht ten eenenmale onvruchtbaar te zijn.

B o ekit batoe zijn rotsen.

Batoe ampar zijn steenachtige grouden.

Pampang of Pantoi zijn rivieroevers of waarden.

T'a nè-ag ong zijn begraafplaatsen.

Pĕna paän, ook wel wa dah pĕhadjatan geheeten, zijn offerplaatsen. Deze vindt men doorgaans aan de mondingen der rivieren, bij bijzonder gevormde rotsen of boomen, ook wel bij plaatsen in de rivieren, wegens de daar aanwezige stroomversnellingen of uit andere hoofde gevaarlijk voor de prauwvaart.

K e mäjoen of La āng hoembang zijn bamboebosschen, maar deze vindt men alleen in het distrikt Boven-Doesson. Een uitgestrekt bosch ligt aan de Soeko-rivier achter Kampong Siroen.

Omtrent de producten, op en in de onbebouwdegronden gevonden, verzamelde ik de volgende aanteekeningen.

De deugdzaamste houtsoorten zijn: IJzerhout, in Midden-Doesson Onglin, in Beneden- en Oost-Doesson Tawoediën, in Mengkatib Tabaliën geheeten; verder Oempas, Kajoe batoe, Pangin, verschillende Madangsoorten, Tjangal, bij de kampongs Pepas en Sikan; Maladjihing; Marahatak; Sòerě, zwart van kleur, in hoedanigheid het ebbenhout evenarende en alleen aangetroffen in het 
gebied der Téwé-rivier en eindelijk het Koesi, waarvan alleen de soms kolossale bladwortels voor gebruik in anmerking komen. Het hout daarvan is fraai donkerbruin van kleur maar zeer moeilijk te bewerken.

Al deze worden in het oerwoud aangetroffen en bij voorkeur gebezigd voor huispalen, vaartuigen en brugplanken. De volgende soorten leveren uitstekend timmerhout:

In de distrikten Boven- en Midden-Doesson: Lampong; tal van Lanan-soorten; Karamboekoe; Meroemboeng: Orai; Bansoei; Kalapé; Tampoeraoe; Hanjaloetoeng; Bantoengan ; Mongsopat; Bantérang; Tinak-pampoeloe; Menjaraoe: Tontong; Bawang, aldus genoemd naar de kleur en de eigenaardige reuk van uien; Mansalioe; Banoewang-laring; Pararaoe; Bantoewé; Irat; Rĕsak, Boengoer enz.

In de onderafdeeling Boentok: Blangiran, Pirawos; Gĕlamsoorten : Rawali, Seloembar, Kapoenoga; Lanansoorten : Marsihoeng, Masintan, Simpoer, Alaban, Mengaris; Damar-poetih; Bangkirai; Ambalaoe; Merbaoe, Garoenggang enz.

Van deze soorten worden ook wel minder duurzame vaartuigen, zoomede planken voor den buitenwand van woningen en roeispanen vervaardigd.

Rossok is een in de bosschen veel voorkomende wilde kaneelsoort, waarvan de bast en de vruchten gegeten worden.

Van de harssoorten verdienen in de eerste plaats vermeld de zoozeer bekende Mata koetjing, welke te Moeara Téwé verhaudeld wordt tegen f 18 tot f 30 per pikoel en te Bandjarmasin tegen f 25 tot $\mathrm{f} 40$, en Boer a of $\mathrm{T}$ ĕla n, een zeer inferieure soort, zwart of bruinzwart van kleur, welke laagsgewijze onder den grond - soms zeer diep - gevonden en uitsluitend tot verlichting der woningen van zeer minvermogenden of ver in het binnenland wonende Dajaks gebezigd wordt.

Andere soorten zijn Karamboekoe, Bensoei, Kalapé, Bèmbéré, Oerai, Lampong en Rĕsik, allen in de distrikten Boven- en Midden Doesson.

In de onderafdeeling Boentok: Paloean; Mihambang; Klesi; Hamboemoet, Karangan enz. De bekende, welriekende Menjan komt in deze afdeeling niet voor.

Van oneindig meer beteekenis zijn de getah - Nato of $\mathrm{Njatoï}$ - soorten, waarin vooral in de laatste jaren, wegens het stijgen der Europeesche marktprijzen, een zeer levendige handel gedreven 
wordt ${ }^{1}$. De meest gewilde soorten zijn: A. de guttapercha opleverende als: $1^{\circ}$. Getah Samboen of Nato oeloei en Getah Bringin, beiden ter waarde van circa f 250 het pikoel; $2^{\circ}$. Getah Doejan ter waarde van ongeveer f $55 ; 33^{\circ}$. Getah Toendjoeng en Getah Hangkang, beiden ter waarde van ten naastenbij $\mathrm{f} 14 ; \mathrm{B}$. de ca outchouk of gomelastiek opleverende, als $1^{\circ}$ Getah dangoe, ook wel Gitaän of Klimpit geheeten, van eene marktwaarde van van $\mathrm{f} 100$ het pikoel; 2' de Kwĕtei ter waarde van $\pm \mathrm{f} 70$.

Rottansoorten ${ }^{2}$. Men onderscheidt twee soorten van rottan nam.: Wé roentihan en Wé Koesoeh, naar de wijze roentih - waarop zij van den schors ontdaan worden alvorens in den handel gebracht. Tot de eersten behooren de meest gezochten voor de Europeesche markt, n.l. Héké of Taman - in het distrikt Mengkatib Saliah geheeten - Boejoeng, Tapah en Irit. Alle overigen zijn Wékoesoeh zooals: Semoeli, Bamboelaoe, Semoelidatai, Lintoeng, Mea, Noengkan, verder Manaoe, Sidong en Danan, allen ter dikte van ongeveer een mansarm; Djoewah en Persikan, beiden een duim dik, Tangkiris, Laloen, Toento, Ramoro enz.

Voor het vlechten van reepen ten behoeve der vlotten bedient men zich van zeer dunne rottansoorten, bestempeld met den alge-

1 De inning van getah, de fijnste soorten niet uitgezonderd, geschiedt zoo roekeloos mogelijk, door de boomen eenvoudig om te kappen. Bij herhaling werd bij hoofden en bevolking er op aangedrongen om de exploitatie op dezelfde wijze te verrichten als in Suriname bij den Balataboom (= Eng. bullet tree) welke een naar men zegt, een uitstekend surrogaat voor Nato oeloei oplevert. In den bast worden schuin naar beneden toeloopende insnijdingen aangebracht, welke elkaar kruisen en waarlangs het sap afvloeit om onderaan opgevangen te worden. Dikwijls ook brengt men graatvormige insnijdingen in den stam.

Men toonde zich wel genegen deze wenken op te volgen bij boomen in de onmiddellijke nabijheid der kampong, maar ten aanzien van die in het oerwoud vreesde men dat anderen ze zouden omkappen, waardoor voor hen de groote winsten verloren zouden gaan.

Zeer zeldzaam worden de zoo dure guttapercha- en eaoutchouk-soorten zuiver in den handel gebracht. De Maleische handelaren bedingen de levering der grootst mogelijke hoeveelheden tegen een minimum van geld of geldswaarde, met het gevolg dat de inzamelaar die soorten met andere ingredienten zoodanig vermengt dat zij, hoewel uitwendig daaraan niets te bespeuren is, soms totaal bedorven of onbruikbaar te Bandjarmasin worden aangebracht.

2 Rottan heet in Boven- en Midden-Doesson Wé en in de onderafdeeling Boentok Oewai. 
meenen naam van Wé-anak. Bij voorkeur gebruikt men daarvoor de Semoeli en Ikajangkis.

De Wé-djĕrĕnang, welke de onder den naaın van drakenbloed bekende verfstof oplevert, komt alleen voor in de bovenstreken van het distrikt Oost-Doesson.

De bijen, welke was en honig opleveren, nestelen bij voorkeur op Kaladan, Djingah, Koepang, Poelantan, Djĕlapat en Wilasboomen. Zijn zij eenmaal daarin aanwezig, dan dragen die boomen in de distrikten Boven- en Midden-Doesson den naam van Poensi; in de onderafdeeling Boentok dien van tinggiran of tinggiran manji.

Vooral de landstreek, meer bekend onder den naam van Telokměrawé, grootendeels liggende in het distrikt Mengkatib, is bijzonder rijk aan produktieve tinggirans. Zelfs heb ik daar boomen gezien, waaraan meer dan 150 bijennesten werden geteld.

Luidens een brief dd. Juli 1860 van den civiel gezaghebber te Marabahan, gericht aan den $w^{\mathrm{d}}$ Resident, bevonden zich toenmaals aldaar minstens 200 tinggirans, welke 's jaars een zuivere winst aan was - de honig niet medegerekend - van ongeveer f 1000 afwierpen.

De boomen, welke plantenvet opleveren zijn vooral: Masoepang bij de kampongs Pèpas, Paring-lahoeng, Boekoean of Roedjih en Sikan; verder Tingkawang; Tingkawang-tělor; Palépèk, Katiaoe en Mengkabang. De Katikoe-tandoek en Poentik worden alleen in de onderafdeeling Boentok aangetroffen.

Tot dusver schijnt bij den Europeeschen handel zeer weinig vraag naar dit artikel te zijn. Toch leveren de bosschen een verbazenden overvloed daarvan op, te veel voor de voorziening in de behoeften der bevolking.

Behalve als geneesmiddel wordt het door haar voornamelijk gebruikt als surrogat voor braadolie.

In 1898 werden jonge plantjes van al deze boomen naar's lands plantentuin te Buitenzorg gezonden.

Bamboe (hoembang) komt overvloedig en van allerhande soort in 't wild groeiende in de bosschen voor; aangeplant wordt zeer weinig. De meest gewilde soorten zijn: Bĕtoeng, alleen in de Téwéstreek, voornamelijk bij kampong Benangin; Porring; Tèlang, Tamiang, welke, gespleten en gevlochten, gebruikt wordt als omwanding voor woningen; Boekoean of Bamboe doeri; Bambaloèwang en Bakaharang. 
Palmen zijn schaarsch en slechts vertegenwoordigd door de navolgende :

Hanaoe of Arènpalm. Noch de bereiding van touw uit de vezels, noch van drank of suiker uit het sap der vruchten, noch van confituren uit de jonge vruchten is bekend, ten minste men legt zich er niet op toe. Alleen de topblâren worden gebezigd als dekblad voor sigaretten. Deze palmsoort komt het meeste voor in de Téwéstreek waar hij, evenals de Nanga of Sĕgaoe - de welbekende roembia of Sagoboom - door Toemenggoeng Mangkoesari, naar men zegt, werd ingevoerd; maar van deze laatste weet men evenmin het zoo gezonde voedingsmiddel daaruit te winnen.

Van de Njiboeng of Niboeng - elders meer bekend als Tolla worden latten vervaardigd ten behoeve van den huizenbouw.

Andere palmsoorten zijn nog de Binrang, de Sirang en de Pinang. Deze laatste komt voor als kultuurgewas en als voortbrengsel der bloekargronden.

Boomschors dient tot het vervaardigen van kleedingstukken en sirappen voor dakbedekking. Een menigte bastsoorten worden daartoe aangewend, maar de voorkeur verdienen Bangkirai, Lanan, Amiwaoe, Garoe en Galam.

K leurstof leverende gewassen bestaan zoowel in boomen als slingerplanten en knolgewassen. De navolgende mogen hier vermeld worden: Kajoe hipang of Sapanhout; Ehang of Oewar, een boom uit welks bast een bruin zwarte kleur - tevens looistof voor touw- en houtwerk - gewonnen wordt; Bangkoedoe oetan en een wortel met name Koenjit wakai, welke een gele kleurstof oplevert. De overige koenjitsoorten worden aangeplant.

De navolgende knolgewassen worden genuttigd in tijden van groote schaarschte aan rijst en andere voedingsmiddelen: Ganrong (=mal: Gadoeng); Banai; Baïran: Oewéimpit en Lamajoet.

Medicinale planten. Als zoodanig komen hier in aanmerking: Wakai ${ }^{1}$ Saboei of Pĕnawar sampai, bitter van smaak, een goed koortswerend middel naar men zegt; W. Mangkalagit: W. Moenoeng; W. Kalimpit; Batoesiké; Kĕnamoet; Latak najoe; Tĕmpĕlạk noenae; Tẹ̆mpĕlak bĕné; Tèrak, Kwatik en Baugkirang.

De gewone dakbedekking is van boombast of hout, in den vorm van sirappen. Waar deze moeilijk verkrijgbaar zijn, bezigt men alangalang.

${ }^{1}$ Wakai beteekent klim- of slingerplant. 
In de moerassige streken van het distrikt Mengkatib en op enkele plaatsen in de Téwé- en Lahei-rivieren groeit een rietsoort Poeroen - waarvan zakken en matten gevlochten worden, zeer gezocht in den handel.

Verder dienen als nuttige gewassen te worden genoemd: verschillende soorten van wilde pisang, voorkomende op de bloekaren zeer jonge balinggronden. Uit de vezels van den stam wordt door rooting zeer sterk touw bereid. Dit wordt ook verkregen uit de vezels van de Wakai Kliat en Wakai Ekat, waaraan men, voor vischtuig, de voorkeur geeft boven het eerste

Voor hen, die zich lang in de bosschen moeten ophouden, leveren de Wakai Salampati, W. Labang, W. Gador en W. Sambaitandjong goede wilde sirih op, terwijl van de W. Pangaroija het overvloedige sap dient om bij gemis van water den dorst te stillen. Het sap daarvan is zeer overvloedig, helder, fristh en smakeloos.

De Hilat is een heestergewas, waarvan de versche, dus nog groene blâren, gebruikt worden als dekblak voor sigaretten.

Eindelijk verschaffen de talrijke mierennesten in de boomen een voortreffelijke kleefstof - $\mathrm{kasipé} \mathrm{-} \mathrm{tot} \mathrm{bevestiging} \mathrm{vau} \mathrm{hand-}$ vatsels aan wapens, werktuigen enz.

Vogelnestgrotten vindt men in menigte in het distrikt Midden-Doesson, n.l. aan de Boven-Téwérivier rondom het Angagebergte, in de buurt vau Kampong Benangin. De meest produktieve zijn het eigendom van Toemenggoeng Mangkoesari en diens zwager Sahadan, distriktshoofd van Boven-Doesson; verder in het gebied der kampong Sampirang, mede aan den bovenloop der Téwé-rivier, en in de rotsen in het stroomgebied der Loeang (linker bronrivier der Téwé): in de streek genaamd Liang Djoekan, nabij kampong Toengka, aan den bovenloop der Montalatrivier en eindelijk in het gebied der kampongs Piuré en Lemo. Ook aan den bovenloop der Laheirivier op den berg Boeroeng Ngajoe, nabij de grenzen van het sultanat Koetei, moeten zich vogelnestgrotten bevinden, het eigendom van eenige Paré-Dajaks aan de Mahakam. De opbrengst daarvan wordt bij den in de nabijheid daarvan wonenden Goesti Etêt, alias Pangeran Djaija Kasoema, tegen tabak, zout enz. ingeruild.

In het distrikt Boven-Doesson worden dergelijke grotten aangetroffen aan de Djaān- en Toehoeprivieren, de eerste een rechter, de laatste een linker-zijrivier der Barito, daar Moeroeng geheeten. 
Iu de laatste jaren is de prijs der eetbare vogelnestjes zeer gedaald. Was die in 1897 te Moeara Téwé voor eerste kwaliteit nog. f 25 het kati, tegenwoordig kon zij ter nauwernood f 15 halen.

Het dieren rijk levert o. m. rhinocerossen, bantengs, beren, tal van slangen en apensoorten en zeer fraaie vogels w. o. vermelding verdienen de welbekende parelfazant en de pauw, deze laatste voorzien van een witten, zilverglanzenden opstaanden kraag.

Zoover bekend bestaat de minerale rijkdom van den bodem in het navolgende :

Di a mant. De vindplaatsen hiervan ziju voornamelijk de Mewien - linker-zijrivier der Barito - en de Djoeloei - rechter-bronrivier der Barito —, beiden in het distrikt Boven-Doesson; nergens anders naar 't schijnt.

Goud. Dit wordt bij lagen waterstand door middel van wassching gewounen uit de bedding der Baritorivier of de daarin aanwezige zandplaten en droogten en uit hare bronrivieren in het distrikt Boven-Doesson. Daartoe bedient men zich van de doelang, zijnde een groot, diep houten bord of bak, die voortdurend in schommelende beweging wordt gehouden, terwijl het water er over stroomt. Dit is doorgaans het werk van vrouwen, kinderen en bejaarden, die daarmede per persoon een daggeld van f 0.10 tot f 0.30 verdienen.

In de Boesang en de Djoeloei wordt, naar men zegt, op die wijze dagelijks voor $\mathrm{f} l$ tot $\mathrm{f} 2.50$ aan stofgoud gewonnen.

Het aldus gewonnen goud kost te Moeara Téwé $\mathrm{f} 70$ de thail van 0.054 K.G.

Aan den bovenloop der Barito of Moeroengrivier schijnt het niet voor te komen.

Op enkele plaatsen in het districkt Midden-Doesson, welke van ouds. her als goudhoudend bekend staan, als Boekaoe en Béloeng, achter kampong Malawakèn, wordt de grond uitgegraven en daarna gewasschen.

Antimonium. Tot dusver is dit alleen nog maar aangetroffen in den Midden- en Bovenloop der Laheirivier en hare zijrivieren. Daar komt het voor in den vorm van bijna zuiver antimoniumglans met sporen van lood en bismuth.

IJzer. Voorheen was de inlandsche ijzerindustrie zeer in bloei; maar met het toenemen van onzen invloed vermeerderde ook de concurrentie met de Europeesche ijzer- en staalwaren en daartegen was $\mathrm{zij}_{\mathrm{j}}$ niet opgewassen. Het ijzererts werd toenmaals bewerkt op of nabij de vindplaatsen; en o. m. zijn thans nog te Boekaoe en bij 
de monding der Montalatrivier de overblijfselen dier industrie te zien.

Toch blijft de bevolking hooge waarde hechten aan wapens, vooral mandaoe's, vervaardigd van inlandsch ijzer. Thans worden deze uit de Mahakam (Koetei) over land naar de Meroewai - linker zijrivier der Laoeng - aangevoerd, vanwaar zij verder hun weg vinden naar Boven- en Midden-Doesson.

Steenkolen. Hiervoor schijnt in deze afdeeling, speciaal de distrikten Boven- en Midden-Doesson, een groote toekomst te liggen. Steenkolenbeddingen vindt men in het distrikt Midden-Doesson:

$1^{0}$ aan de beide oevers der Baritorivier te Poensoeng Bara, Moekoet en Lowé; $2^{\circ}$ aan den benedenloop der Laheirivier, voornamelijk aan de Soengei Poeroen en Soengei Inoeh; $3^{\circ}$ aan den benedenloop der Téwé-rivier, in 't bizonder te Lampoei, Sikoei en Tadjoek; $4^{\circ}$ aan dien der Lemorivier en hare linker- en rechterzijrivieren; $5^{\circ}$ aan dien der Purérivier; $6^{\circ}$ aan dien der Benanginrivier tegenover kampong Bintang Ninggi: $7^{\circ}$ aan dien der Inoehrivier ten zuiden van kampong Boentok Ketjil, maar hier zijn zij naar men zegt van inferieure kwaliteit; $8^{\circ}$ an den bovenloop der Montalatrivier.

In het distrikt Beneden-Doesson worden, zoover nog bekend, alleen steenkolen aangetroffen aan den rechter-bovenloop der Ajoehrivier.

Volgens geruchten moet het distrikt Boven-Doesson rijk zijn aan steenkolen. Zeker is het dat zich te Bakanoen en te Moeara Oesoem hooge, steenkolen bevattende rotsen aan de oevers der Moeroeng bevinden.

De exploitatie van steenkolen is uitsluitend in handen van Maleische handelaren te Moeara Téwé, werkende met voorschotten, hoofdzakelijk van den kapitein-Chinees te Bandjarmasin.

De steenkolen, gelegen op de sub 1 tot 4 genoemde vindplaatsen - de overige schijnen nog niet de aandacht van den handel getrokken te hebben - worden alleen ontgonnen, voor zoover zij aan de oppervlakte liggen, door verwijdering der daarop rustende aardlaag. De uitgegraven steenkool wordt aan den oever opgestapeld, waar zij blijft liggen, blootgesteld aan de verschillende weersinvloeden, tot het vlot gereed is tot afvoer naar Bandjarmasin.

De daartoe bestemde boonstammen worden in den drogen tijd gekapt en bij zeer hoogen waterstand over het verdronken land of langs gezwollen beekjes naar de plaats van bestemming gesleept, waar zij tot een vlot worden saamgebonden, voorzien van een bamboe-hekwerk, waarbinnen de steenkool wordt opgeladen. 
Gewoonlijk wordt per vlot 100 , hoogstens 200 ton steenkolen afgevoerd; en om dit resultaat te bereiken heeft men doorgaans ruim een jaar tijd noodig.

Te Moeara Téwé kost de ton steenkolen f 4, te Bandjarmasin het dubbele.

A ardolie schijnt nergens anders aanwezig te zijn dau in de bergstreken van het distrikt Oost-Doesson. Bij zeer lagen waterstand der Barito rivier wordt in de bedding daarvan, vóór kampong Lémo, een bron gevonden waaruit een bruin wit vocht opborrelt; maar in hoever dit aardolie is kan niet gezegd. Zoover mij bekend, is deze vloeistof nooit onderzocht.

Zo utbronnen - Soepan geheeten - vindt men bij kampong Moeara Limpangan aan de boven-Téwérivier en aan de Toehoep-, de Boemban- en Menawien-rivieren, allen van het distrikt Boven-Doesson.

Daar wordt nog altijd zout gewonnen; maar in de Téwé heeft men dat bedrijf laten varen omdat, na het ontstaan van een meer geregelden toestand in deze afdeeling, voortdurend voldoende zoutaanvoeren van het pakhuis te Boentok plaats hadden.

Regel is, dat er geene onbebouwde gronden zijn, uitsluitend gebezigd voor de inzameling van sommige produkten.

Gebruikelijk is het evenwel om gronden, waarop deugdzaam hout, rottan en getahboomen in beduidende hoeveelheid voorkomen, niet te ontginnen, maar te reserveeren voor den houtkap en de inzameling der produkten.

Eene uitzondering hierop maakt - luidens den brief van Kiai Dĕmang Wangsa Negara aan den militairen kommandant te Marabahan dd. 23 Januari 1859 - de landstreek, gelegen in het distrikt Mengkatib, en langs den rechteroever der Baritorivier zich uitstrekkende van de Soengei Mĕrawé tot Soengei Poening. Zij munt uit door de menigte produktieve tinggirans (zie hetgeen boven omtrent was en honig werd medegedeeld), voor de exploitatie warvan die landstreek wordt gereserveerd ${ }^{1}$.

Afzonderlijk jachtterrein vindt men nergens. De jacht is vrij en hẹt wild overvloedig, uitgezonderd in de moerassige bosschen van

1 Vóór den grooten opstand van 1859 behoorde zij aan Toemenggoeng Soerapati, die daarvan werd ontzet luidens den brief van den militairen commandant te Marabahan dd. 1 Maart $1860 \mathrm{~N}^{\circ} 30$, gericht aan den Děmang Marta Djaija, Eerste hoofd van Karaoe. Tegenwoordig is zij in 't bezit van Demang Pati Anom, distrikshoofd van Mengkatib. 
het distrikt Mengkatib. Afgebakende weideplaatsen heeft men ook niet, omdat het tamme vee schaarsch is. Buffels en runderen houdt men er alleen op na om bij groote feesten en plechtigheden te slachten.

Voor ontginningen zijn geen bepaalde gronden aangewezen; het staat een ieder vrij zijne tuinen en ladangs aan te leggen waar hij wil. Bij voorkeur kiest hij daartoe de gronden langs de rivieren; voor tuinen in de onmiddellijke nabijheid der kampongs; voor ladangs op hoogstens drie paal afstand van den oever.

De bevolking kent niet anders dan roofbouw. Een boschperceel wordt opengekapt en afgebrand en vervolgens beplant met padi en daartusschen allerlei gewassen tot voedsel, versnapering of van huishoudelijk belang als cassavesoorten, suikerriet, maïs, pisang, knolplanten, lombok, tèrong, komkommersoorten, kapas, indigo, tabak enz.

Dikwijls ook vindt men daarop medicinale planten, en gewassen waaraan het vermogen wordt toegeschreven de booze geesten van het veld verwijderd te houden en alzoo den eigenaar een goeden oogst te verzekeren.

Van wisselbouw heeft de bevolking hoegenaamd geen begrip. Na den padioogst wordt in Boven- en Midden-Doesson de ladang met al wat er op staat verlaten, om het volgende jaar hetzelfde werk op een andere plaats te hervatten.

Slechts de himbagronden acht men eerst na twee, soms na drie jaren uitgeput. De bloekargronden worden doorgaans na 8 à 10 jaren weer in gebruik genomen.

Zijn zij echter met alang-alang begroeid, dan worden zij niet meer in kultuur gebracht, omdat, met de gewone den inlander ten dienste staande middelen, die grassoort niet is uit te roeien en meu opziet tegen de moeite van bewerking en schoonhouding.

In de onderafdeeling Boentok worden lage gronden, bij hoog water blank staande, - uitgezonderd diepe moerassen - 3 à 4 jaren achtereen bebouwd en daarna gedurende 5 ì 6 jaren verlaten. Verreweg de meeste gronden zijn evenwel van regen af hankelijk; deze worden in den regel slechts voor 3 à 4 jaren in kultuur gehouden om daarua 5 tot 12 jaren braak te blijven, ten minste indien zij dan niet tot den toestand van oude bloekar of jonge baling zijn vervallen.

Omtrent de staatkundige en ethnographische verhoudingen der bevolking in de Doessonlanden kan het volgende worden medegedeeld. 
De daar aangetroffen Dajaksche stammen zijn:

$1^{\circ}$ Biadjoe; $2^{\circ}$ Sihong; $3^{\circ}$ Maänjan; 4.0 Pakoe-karaoe; $5^{\circ}$ Lawangan; $6^{\circ}$ Doesson; $7^{\circ}$ Bajan; $8^{\circ}$ Toboeijan; $9^{\circ}$ Siang; $10^{\circ}$ Oets danoem en $11^{\circ}$ Zwervende Oets. Verder heeft men Taboeijan Montalat, Taboeijan Boenoö of Lahei en Bajan Tengah; maar deze drie zijn hoogst waarschijnlijk geslachten, die zich in den loop der tijden van den hoofdstam gescheiden en verder zelfstandig ontwikkeld hebben. Eindelijk bestaan er nog Karawantan-Dajaks, maar grootendeels zijn deze reeds opgegaan in de overigen. Soms herkent men hen nog aan de taal. Van al de genoemde stammen is het land van herkomst onbekend naar men zegt, behalve van de Karawantan en Biadjoe, die van de Kapoeas moeten binnen gedrongen zijn.

Omtrent hunne verspreiding geeft de hierbij gevoegde kaart een overzicht.

Oorspronkelijk bewoonde een Dajaksche familie of boeboehan éen huis, dat in verschillende afdeelingen verdeeld en veelal door een ijzerhouten palissadeering omgeven was. Zulke woningen of versterkingen, waarin 100 tot 200 soms meer zielen verblijf hielden, dragen den naam, in Boven- en Midden-Doesson van bètang; in de ouderafdeeling Boentok van Baleh Pawangan of $\mathrm{Baleh}$ besa ar.

Dergelijke versterkte plaatsen vindt men tegenwoordig nog alleen in Boven-Doesson, n.l. van den stam der Oets te Moeara Djoeloei onder hun hoofd Toemenggoeng Angi en, aan den rechteroever der Mĕroewai, nabij hare uitmonding in de Laoengrivier, van de Tèloe njarings onder hun hoofd Dalam bin Sangalang '.

Overigens vindt men nog bètangs, maar zonder palissadeering, in geheel Boven-Doesson en in Midden-Doesson, benoorden de hoofdplaats Moeara Téwé ${ }^{2}$. Ten zuiden daarvan en in de onderafdeeling Boentok bestaat die gewoonte niet meer, maar scheiden de kindéren bij huwelijk uit de ouderlijke woning om er zelve een te betrekken.

Wat de administratieve indeeling betreft, - - de Doessonlanden zijn verdeeld in twee onderafdeelingen, n.l. Moeara Téwé

\footnotetext{
1 Deze laatste versterking werd ongeveer 50 jaren geleden opgericht op last van Soerapati, om het stroomgebied van de Laoeng, en daarmede dus ook Boven-Doesson, te beveiligen tegen de roof- en sneltochten der Dajaksche stammen van de boven-Mahakam of Koeteirivier.

${ }^{2}$ Eene uitzondering hierop maken de kampongs Nihan en Lahei I.
} 
onder het direkt bestıur van den afdeelingschef, en Boentok met een kontroleur.

De eerste bestaat uit het distrikt Boven-Doesson met de twee onderdistrikten Siangmoeroeng en Laoeng en het distrikt MiddenDoesson met de onderdistrikten Téwé en Montalat; de tweede uit de distrikten Beneden-Doesson, Oost-Doesson en Mengkatib. In hoeverre de administratieve indeeling des lands samenvalt met die in stammen is eveneens op de kaart na te gaan.

Aan het hoofd der distrikten en onderdistrikten staan door het gouvernement bezoldigde inlandsche ambtenaren, die den titel hebben van "kiai" indien zij Mohammedanen, van "Demang" indien zij Dajaks zijn. Aan hen zijn de kamponghoofden of "pembekels" ondergeschikt.

Zooveel mogelijk worden de Dajaks en Maleiers van elkander gescheiden en onder hunne afzonderlijke hoofden gesteld ${ }^{1}$.

1 Toen deze afdeeling onder ons bestuur kwam werden er bijna geene Maleiers aangetroffen. Deze drongen eerst later binnen, en hun intocht stond in verhouding met de toeneming van onzen invloed. Zij, meestal handelaren van Marabahan (= Bekompai), vestigden zich eerst aan de Baritorivier, vervolgens aan hare groote zijrivieren, op plaatsen bizonder geschikt voor den handel, vanwaar zij de geheele -landstreek, vooral de nabijgelegen stroomgebieden beheerschten, zooals te Bangkoeang, Tandjong-Djawa, Toempoenglaoeng, Moeara Téwé, Moeara Lahei II, Moeara Laoeng, Poeroe Tjahoe enz., waar resp. de Karoe, de Ajoeh, de Montalat, de Téwé, de Lahei, de Laoeng met de Boemban en de Soeko onder hunnen invloed kwamen. Vandaar drongen zij langs die rivieren in het binnenland en vestigden groote handelscentra, te Waloer aan de Montalat, te Moeara Benangin aan de Téwé, te Moeara Inoeh aan de Lahei, te Batoe boeah aan de Laoeng enz. Zij vermengden zich door huwelijk met de Dajaksche bevolking d. i. de „orang doesson" van alle stammen - de naam "Dajak" wordt beschouwd als een scheldnaam -- en daaruit is een ras ontstaan dat met de Maleiers den godsdienst, n.l. den islam, met de Dajaks de zeden, gewoonten en gebruiken gemeen heeft en daarom met den naam van "Bekompai-Doesson" wordt bestempeld. Nagenoeg alle kamponghoofden in het distrikt Boven-Doesson behooren daartoe. Als hun hoogste vertegenwoordigers beschouwen zij Toemenggoeng Djidan, alias Radèn Depati Mangkoe Negara, zoon van wijlen Soerapati, mede uitgesloten van de amnestie, en Toemenggoeng Mangkoesari, vader van het tegenwoordig distriktshoofd van Midden-Doesson, voormalig ijverig aanhanger der sultanspartij, woonachtig te Moeara Benangin aan de Téwérivier.

Door hun verwantschap met Marabahan blijven zij die plaats beschouwen als het centrum van handel en godsdienst, zoodat zij daarmede voortdurend voeling houden.

Van de genoemde handelscentra en meer anderen nog in opkomst, dikwijls diep in 't binnenland, zoo goed als onbereikbaar voor den besturenden ambtenaar, gaat op de omliggende bevolking een overwegenden invloed uit, waarvan niet altijd gezegd kan worden dat hij ten gunste van ons bestuur is. 
Het Maleische bestuur is ingericht volgens dat te Bandjarmasin en elders in de benedenlanden, zooals vastgesteld bij besluit van den Gouvernements-commissaris dd. 11 Juni $1860 \mathrm{~N}^{\circ}$ 24. Van volkshoofden is natuurlijk in 't geheel geen sprake; anders is dit evenwel bij de Dajaks. Deze zijn van oudsher, gelijk boven vermeld, verdeeld in stammen, die zich gesplitst hebben in familiën. Aan het hoofd eener kampong moet, volgens de adat, iemand staan afkomstig van den eersten stamvader. Is zulk een persoon niet te vinden, dan wordt de keuze gevestigd op het naaste mannelijke lid, ook in-de vrouwelijke linie. De betrekking is dus niet afhankelijk van eene verkiezing, maar erfelijk in het geslacht. Wegens de groote individualiteit, den Dajak eigen, is hij wars van elk éénhoofdig gezag en het kamponghoofd heeft mitsdien over zijne onderhoorigen een patriarchalen invloed, waaraan allen zich onvoorwaardelijk onderwerpen.

$\mathrm{Bij}$ de afdoening van ingewikkelde geschillen roept hij een soort van adviseerend college bijeen, een raad van oudsten, van invloedrijke mannen, zooveel mogelijk uit dezelfde familie, anders uit denzelfden stam. Zij zijn altijd de steunpilaren der traditie, die zij mondeling bij de bevolking levendig houden.

Onder den steeds toenemenden invloed van ons centraliseerend gezag en, in 't gevolg daarvan, den islam, met zijne rustelooze propaganda, werd getracht in dat kampongbestuur verandering te brengen, door het in te richten als dat van de maleische bevolking. In 't algemeen kan gezegd worden, dat die poging geslaagd is in de kampongs langs de Barito, maar een gedeelte van BovenDoesson, verder de kampongs langs de Toehoep, de Dahei, de Téwé, de Ajoeh en een deel van de Karaoe, zoomede de bergstreken van het distrikt Oost-Doesson zijn daarvan nog bevrijd gebleven. Toch moest ook daar het dorpsbestuur eenigermate worden gewijzigd in ' $l$ belang der administratie en eener geregelde belastingheffing.

Vorsten bestaan in deze afdeeling niet, tenzij men daartoe Goesti Mohamad Sĕman en zijn vollen neef, tevens schoonzoon, Goesti Mohamad Arsat, broeder van den verbannen Pangéran Parbatasari zou willen rekenen, waarvan de eerste bij Stbl. 1862 № 119 uitgesloten is van de amnestie. Hij is de zoon van wijlen Pangéran Antassari, de pretendent van den Bandjarmasinsche troon en zetelt te Bras koening, aan de Mĕnawienrivier in het distrikt Boven-Doesson, waar hij een miniatuur hofhouding houdt en alle 6. Volgr. VIII. 
gebruiken van het voormalige groote hof zijner voorouders zooveel doenlijk doet naleven.

Hoewel men hem en zijnen hofstoet als vreemdelingen beschouwt, wordt hij toch door hoofden en bevolking, ja zelfs door onze bezoldigde distriktshoofden, en door hen die uit de benedenstreken, vooral van Marabahan, daar ten handel komen, als vorst gehuldigd en met "Salira" d. i. Sultan aangesproken.

Hij heeft in de kampongs een eigen bestuur naast het onze; verleent titels van adeldom, als pangeran en dergelijke; heft belastingen en tollen in natura en in geld, ook van de bosohproducten, en laat de zeer ruime woningen van hem en Goesti Arsat te Bras koening en aan de Riam Palembang (Boembanrivier) door de bevolking in heerendienst bouwen en onderhouden.

Eindelijk voert hij op zijrie reizen te water aan den voorsteven van zijn vaartuig de gele sultansvlag met de halve maan.

De verhalen, dat hij en de zijnen een kommervol bestaan lijden, zijn allen-leugenachtig en verspreid om het bestuur te misleiden.

De waarheid is dat het oude Bandjarmasinsche rijk verplaatst is naar het uitgestrekte distrikt Boven-Doesson 1, waar het op kleinere schaal is blijven voortbestaan.

Eindelijk vindt men nog aan den uitersten bovenloop der Laheirivier de afstammelingen en bloedverwanten van wijlen Goesti Djamal. Hun hoogste vertegenwoordiger is Goesti Etèt, alias Pangeran Djaija Kasoema. Door hunne voortdurende vermenging met Dajaksche vrouwen is van hun adeldom niet anders overgebleven dan hun titel, waarop zij zeer prat zijn.

De afstammelingen van al deze vorstentelgen dragen verschillende namen, naargelang van het huwelijk waaruit zij gesproten zijn. Als regel geldt dat de kinderen den stand des vaders volgen ${ }^{2}$. Huwt echter een goesti-vrouw met iemand buiten haren stand, een djabah, dan heeten de kinderen uit dat huwelijk andin.

1 De oppervlakte van dit distrikt is ten naastenbij 1030 vierk. Geogr. mijlen en dus ongeveer zoo groot als de geheele residentie Menado, doch met eene approximatieve bevolking van niet meer dan 16000 zielen.

2 Eene uitzondering hierop maakt Pangeran Bandjarmas, de oudste zoon van den pretendent-Sultan, verwekt bij eene vrouw van zeer lage geboorte (dochter van een matroos op een ijzeren laadschouw). Zijn vader "goesti" zijnde volgens geboorte, had hij nooit den titel van „pangéran” mogen ontvangen. Hierin meen $\mathrm{ik}$ een bewijs temeer te zien, dat Goesti Mohamad Seman zich beschouwt als de wettige vorst in Boven-Doesson. 
Van de kinderen der andins worden de mannelijke afstammelingen "anang" en de vrouwelijke "galoh" genoemd.

De dajaksche bevolking kent geen adel, maar toch bestonden er tijdens het oude sultanaat "da mboeng's" d. z. afstạnmelingen van den Sultan of zijne naaste bloedverwanten, verwekt bij eene dajaksche bijzit, en deze titel bleef erfelijk in het geslacht tot heden toe.

Andere titels zijn nog in volgorde van het aanzien, daaraan toegekend, Pati, Toemenggoeng, Mangkoe, Singa en Djaga, welke alle zeer waarschijnlijk dateeren uit den Sultanstijd.

De inlandsche maatschappij word verdeeld in twee groote categorieën, n.l. vrije lieden - djabah - en onvrije. Tot de eersten behooren de ambtenaren en beambten in dienst van het Gouvernement; het kampongbestuur en zijne beambten; de volkshoofden der Dajaks; de geestelijkheid 1 waartoe ook de hadji's en de balians der Dajak's kunnen gebracht, de handelaren enz. Tot de overigen behooren de slaven of $\mathrm{djipèn} \mathrm{en} \mathrm{de} \mathrm{pandelingen} \mathrm{of}$ sĕrin di ng.

Ofschoon slavernij en pandelingschap reeds lang officieel zijn afgeschaft, is het nog verre dat hoofden en bevolking van die afschaffing doordrongen zijn, vooral in de ver van de bestuurszetel verwijderde streken, zooals de grenzen der omliggende vorstenlanden en het distrikt Boven-Doesson.

De groote schaarschte aan geld, vooral zilvergeld, als ruilmiddel en dientengevolge onbekendheid met de waarde daarvan, zijn oorzak dat men tot slaven en pandelingen zijn toevlucht neemt als een gemakkelijk middel tot geldverkrijging, geldbelegging en schulddelging.

Ook de handelaren in Boven-Doesson maken eeu ruim gebruik van pandelingen om boschprodukten te doen inzamelen, omdat

1 De pengoeloe te Moeara Téwé heeft een zeer eigenaardige positie. Volgens zijn aanstellingsbesluit is hij pengoeloe bij den landraad, dus adviseur en geen mufti, zooals volgens den Reg. Almanak 1900 dl. 2 bladz. 103 bij de landraden te Amoentai, Kendangan en Martapoera gevestigd, krachtens art. 12 ten tweede $\mathrm{C}$ van het Provisioneel reglement enz. vastgesteld bij besluit van.den Gouvts Commissaris dd. 11 Juni $1860 \mathrm{~N}^{\circ} 24$. Hij is ook geen distriktspengoeloe, als bedoeld in dat art. 2 ten tweede $\mathrm{K}$. Toch matigt hij zich de rechten aan van een mufti en wordt zijn raad en advies ingewonnen, zoowel in Boven- en Midden-Doesson als in de onderafdeeling Boentok. Ook worden godsdienstzaken uit de geheele afdeeling te Moeara Téwé voor de geestelijke rechtbank gebracht. Zijne positie is dus ook even tweeslachtig als die der distriktshoofden in Boven-Doesson. 
zij, groote waarden aan lijnwarlen, rijst, zout, tabak, enz. ontvangen hebbende - berekend tegen minstens het dubbele van den marktprijs - niet in staat zijn die op andere wijze te betalen.

Verder bestaat in genoemd distrikt de zoogenaande "adat siangmoeroeng", op grond waarvan de geringste overtreding gestraft wordt met exorbitant zware geldboeten, welke de schuldige nimmer kan voldoen, zoodat hij daarvoor pandeling wordt. Daar zijn schuld niet met zijn overlijden te niet gaat, maar met bijvoeging van woekerrenten op zijne erfgenamen overgaat, geraken deze dientengevolge in den toestand van slavernij.

Ook bestaan daar nog algemeen de tiwah- of doodenfeesten, gegeven ter eere van het overlijden van een aanzienlijk hoofd of eenig invloedrijk persoon, bij welke gelegenheid altijd mensehenoffers worden gebracht. Daartoe worden doorgaans slaven van Koetei en Pasir, meestal Boegineezen, geruimen tijd te voren opgekocht, evenals men dat elders met vee gebruikelijk is te doen ${ }^{1}$.

Het vorenstaande is, in zijn geheel, te beschouwen als eene "inleiding" op hetgeen thans volgt, waarbij de rechten der bevolking op de onbebouwde gronden het uitgangspunt vormen.

lk merk hierbij al dadelijk op, dat het eigenlijk onjuist is, in dit verband van rechten op "gronden" te spreken; men zou eerder moeten spreken van de rechten, door de bevolking uitgeoefend op de bosschen enz., op het kamponggebied voorkomende.

De inheemsche bevolking, de Dajak, vindt bijna uitsluitend zijn bestaan in het inzamelen van boschprodukten, terwijl de flora en fauna der bosschen hem de noodige voedingsmiddelen verschaffen in allerhande boom- en aardvruchten, wortels enz., gevogelte, slangen, apen en diverse wilde dieren. Rijst verbouwt hij nooit

$1 \mathrm{Na}$ den koop worden deze ongelukkigen aan handen en voeten gebonden, vastgelegd, bovendien dikwijls met beide voeten in een zwaar houten blok geplaatst om hun het ontvluchten te beletten. Op die wijze ondergaan zij een gevangenschap van ongeveer twee maander, waarna zij hun vrijheid terug erlangen. Ofsehoon bij den koop bewust van het lot dat hun wacht, schijnt het dat zij dan dat bewustzijn ten eenenmale verloren hebben - naar men zegt tengevolge van het hun toegediende voedsel - zoodat zij zelfs geene poging beproeven om hun leven door de vlucht te redden, ja zelfs elke poging in dien geest, door het bestuur of anderen in het werk gesteld, met minachting afwijzen, in de volle overtuiging dat zij niet gebruikt worden als slachtvee voor een tiwahfeest. Na afloop der plechtigheid worden hüne lijken begraven, maar hunne schedels bewaard. 
voldoende voor eigen behoefte. Aanspraken op den grond kent hij dus niet; wel op de daarop staande bosschen, nuttige boomen, gewassen enz.

Eerst in de laatste jaren heeft hij, voornamelijk door de aanwezigheid van concessiejagers en andere personen, de waarde van den grond leeren begrijpen.

In het distrikt Midden-Doesson behooren de onbebouwde gronden alle tot het gebied eener kampong, zoodat daar geene gronden worden aangetroffen waarop niemand eenige aanspraak kan doen gelden. In de distrikten Beneden- en Oost-Deesson en Mengkatib zijn die gronden het communaal bezit van het distrikt, maar toch komen er stukken voor waarvan het niet bekend is tot welk gebied zij behooren. Niemand kan daarop aanspraak doen gelden, maar dit belet niet, dat ieder die er lust toe heeft, die gronden mag bebouwen of op eenige andere wijze daarvan partij trekken. Geschillen vloeien hieruit nooit voort, omdat de bevolking nog overvloedig over onbebouwde gronden beschikken kan.

Alle kampongs zonder onderscheid - met uitzondering van die in de binnenlanden van Boven-Doesson en den uitersten bovenloop der Téwérivier nabij de grenzen van het ıijk Koetei - liggen aan groote voor prauwen bevaarbare rivieren. Daar langs strekt zich het gebied eener kampong uit, doorgaaus tusschen de monding van twee beekjes; bijv. het gebied der kampong Nihan strekt zich uit langs den rechteroever der Barito, van Soengei Karamoean tot Sei Nihan. Daarua viudt men dat der kampong Lowé tot aan Sei Djoeloein en vervolgens dat der kampong Lahei I tot de monding van den gelijknamigen stroom. Zuidwaarts daarvan ligt het gebied der kampongs Logong en Ipoeh tot de Sei Malawakèn enz.

In het binnenland strekken zich deze kamponggebieden uit tot den oorsprong dier soengei's, meestal een waterscheiding; ofschoon daar ook wel bijzonder gevormde rotsen, boomen van eene bepaalde soort enz. als grenzen worden aangewezen.

Er zijn ook kamponggebieden, waartusschen de greuzen niet vastgesteld zijn, zooals de bovengenoemde kampongs Logong en Ipoeh; verder Boentok ketjil en Kĕmawèn, dan Bintang-Ninggi, Moeara Boetoeng en Mangkiam, eindelijk Paring lahoeng, Roedjih of Boekoean en Pèpas enz., alle van het distrikt Midden-Doesson.

Zij vormen elk een complex van gronden, waarop zich het geslacht heeft gevestigd, waarvan de familie- of kamponghoofden gezegd worden af te stammen, tusschen wie nog geene verdeeling van den grond heeft plaats gehad. 
In het distrikt Boven-Doesson heerscht een onbeschrijfelijke verwarring ten aauzien der grenzen, zoowel van de kampongs als van de onderdistrikten, als gevolg van het gemis aan eenig geregeld bestuur.

Onbebouwde gronden, waarop door een bepaald persoon individueel bezitrecht wordt uitgeoefend, komen zeer veel voor. Dergelijke zijn de "tanah berdatoe", onderscheiden in alkahgronden. soengei of danaoe berdatoe en vogelnestgrotten ${ }^{1}$.

De ladangs worden gewoonlijk door eenige personeu samen aangelegd, d. w. z. de daartoe bestemde boschperceelen ongekapt en afgebrand, waarna ieder zijn eigen padi poot. Dikwijls blijft men daarna ter plaatse bij elkaar in de buurt wonen, om het gewas tegen wilde varkens of ander schadelijk gedierte zooveel mogelijk te beschermen.

Op de aldus tijdelijk ten behoeve van den ladangbouw geoccupeerde gronden verrijzen langzamerhand allerlei vruchtboomen, hetzij die geplant of uitgezaaid worden, wat zeldzaam is, hetzij zij vanzelf opschieten uit weggeworpen of door het gedierte overgebrachte zaden of vruchten.

In den regel staan de aldus opgegroeide vruchtboomen min of meer groepsgewijze bij elkaar, hetgeen "poelaoe" wordt genoemd. Wanneer dus verlaten ladanggronden tot den toestand van bloekar, baling - of himba zijn teruggekeerd, kunnen daarin tal van "poelaoe's" gevonden worden.

Laat nu de oorspronkelijke ontginner of zijne erfgenamen bezitrechten daarop gelden, dan worden dergelijke gronden bestempeld met den naam van "alkah" 2. Deze worden onderscheiden naar hetgeen daarop aangetroffen wordt, in alkah doekoh ${ }^{3}, \mathrm{~d}$. z. gronden met vruchtboomen; alkah tinggiran wanji d. z. gronden met tinggirans enz. - Overdrachtelijk spreekt men ook van een soengei alkah of danaoe alkah, waarmede dan bedoeld wordt een soengei berdatoe of danaoe berdatoe.

Deze laatste bestaan uit riviertjes, gegraven kanaaltjes, tatah geheeten -of meertjes, waarop rechten worden uitgeoefend ten aanzien van de vischvangst, de inzamelingen of den afvoer van boschof landbouwprodukten.

1 In de onderafdeeling Boentok worden deze onderscheidingen der tanah berdatoe niet gemaakt.

2 Eene verbastering van het maleische woord „chalkah".

3 Doekoh $=$ boomgaard. 
Deze rechten heeten geërfd van de voorvaderen en worden door een ieder erkend en geeerbiedigd, behalve dikwijls door de Maleiers, waar het een zeer produktieve streek geldt. De grenzen dezer bezittingen zijn in algemeenen zin vrijwel bekend, maar niet beschreven; en van deze omstandigheid maken zij gebruik om, nadat zij in een kampong gevestigd en "eingebürgert" zijn, den eigenaar in moeilijkheden te wikkelen. De vogelnestgrotten behooren den eersten vinder, wiens rechten op zijne nakomelingschap overgaan.

Huur en verhuur, koop en verkoop zoomede verpanden en wegschenken der vermelde drie categorieën van tanah berdatoe komen voor, ofschoon zeldzaam.

Van deze individueel bezeten gronden, evenmin als van de zoo vischrijke soengei berdatoe en danaoe berdatoe bestaan geschreven stukken of tjaps uit den sultanstijd. Toch doet het besluit van den Resident van Soerakarta, Gouv ${ }^{\text {ts }}$ commissaris voor de Zuider en Ooster Afd. van Borneo dd. Bandjarmasin 1860 No 24 vermoeden, dat dergelijke kunnen hebben bestaan vóór den afstand dezer afdeeling aan het Gouvernement in 1826. Daarin leest men toch dat "het Gouvernement vasthoudt aan het recht, dat tot dusver ieder "nieuw optredend vorst van dat rijk zich voorbehoudt, om ten "aanzien der door zijnen voorganger toegekende apanages zoodanig "te beschikken als hij vermeende te behooren, enz."

Bij gemis aan geschreven documenten worden de grenzen dezer "tanah berdatoe" in het geheugen bewaard en aan het nageslacht overgeleverd.

Het is mij niet bekend geworden, dat ooit zoogenaamde "tanah radja", neutrale gronden, waarop de geschillen tusschen twee kumpongs werden uitgevochten, bestaan hebben. Hoogstwaarschijnlijk is dat niet het geval geweest, want de dajaksche stammen in deze afdeeling waren primitief niets anders dan zwervende horden, zooals thans nog een deel der Oets in Centraal-Borneo. Geschillen werden eenvoudig beslecht door het houden van groote sneltochten, waarbij door beide partijen getracht werd het grootste aantal koppen machtig te worden. Zeker is het dat die tanah radja tegenwoordig. nergens bestaan eu het houden van sneltochten in onbruik is geraakt.

Ontgonnen, doch weer verlaten gronden worden geacht tot den staat van woestheid te zijn teruggekeerd als zij door den ontginner verlaten en wederom begroeid zijn met alang-alang, gras en 
struikgewas of met jong opgaand hout bedekt, kortom als er geen sporen van vroegeren aanplant ineer aanwezig zijn

Dit het geval zijnde, kan de eerste ontginner daarop altijd nog zijne rechten doen gelden.

Als maatstaf neemt men veelal de sirihplant en de cassave (ketella pohon), waarvan na circa twee jaren doorgaans niets meer te vinden is, en in de onderafdeeling Boentok de paggars rondom de ladangs. Zijn deze niet meer te vinden, vergaan of daaruit boomen gegroeid, dan wordt de grond geacht tot den vroegeren staat van woestheid te zijn teruggekeerd, wat gewoonlijk tusschen 5 tot 8 jaren het geval is. Daarna keeren die gronden terug tot het communaal bezit van de kampong - in de onderafdeeling Boentok, van het distrikt - waartoe zij behooren.

Eene uitzondering op deze regel maken de tanah berdatoe.

De regel is dat de onbebouwde gronden, tot eene kampong behoorende, een aaneengeschakeld geheel vormen, waarin enclaves liggen.

In den loop der tijden hebben zich vreeudelingen, d. w. z. personen van een anderen stam of Maleiers, vooral deze laatsten, in een kamponggebied gevestigd, waar zij geleidelijk, ja bijna onmerkbaar het oorspronkelijke element, den Dajak verdrongen of bekeerden, om vervolgens in hunne rechten te treden. Dit geschiedde bijv. in de landstreek behoorende tot het distrikt Mengkatib, vroeger bekend onder den naam van "negeri toedjoe" en gelegen aan den rechteroever der Barito-rivier tusschen de Soengei Mĕrawé en Soengei Poening; te Babai, distrikt Beneden-Doesson, door bekeering tot den islam van het hoofd Toemenggoeng Ibaoe en zijne gansche familie; te Moeara Montalat en Madjalit, ten gevolge der verplaatsing eener versterking in 1861 onder Kiai Rangga Niti Negara; te Moeara Lemo, distrikt Midden-Doessou, door tal van kleine plagerijen der Maleiers in de kampong, waardoor de Dajaks gedwongen werden te verhuizen naar de naburige kampong Pinré enz. In het distrikt Boven-Doesson heerscht ook in dit opzicht een grenzenlooze verwarring; bijv. de Dajaks der kampongs Teloe njaring en Tawéhooi, beiden aan den mond der Meroewai, linker zijrivier der Laoeng, en Teloe liaoe aan den uitersten bovenloop der Laoeng-rivier, behooren tot denzelfden stam en woonden eertijds in elkaars nabuurschap. Sedert hebben zich tusschen de beide eerstgenoemden en de laatsten tal van dajaksche, ja zelfs maleische kampongs geschoven, zooals Toembang Mĕroewai, Batoe boewa e. a. 
Dergelijke vestigingen van vreemdelingen kunnen echter alleen plaats hebben met voorkennis en toestemming van het hoofd, tot wiens gebied het verlangde terrein behoort, na tevoren overeengekomen voorwaarden. Zoo kwain voorheen een uitgestrekt stuk grond aan de Soengei Madoero, rechter zijrivier der Barito, beneden kampong Toempoeng Laoeng, door koop van de daarop aanwezige "tanah berdatoe" in 't bezit van een dajaksch ingezetene der kampong Leong Naga, aan de Téwérivier.

Behalve het zooeven gemelde ten aanzien der "negeri toedjoe" — waartoe ook kampong Babai voornoemd behoorde - schijnen zich in de onderafdeeling Boentok zeer weinig of geen gevallen voorgedaan als boven omschreven. Wel hebben zich Maleiers van Amoentai, Kloewah, Marabahan en andere plaatsen uit de benedenstreken zich daar neergezet; ook vestigden zich enkele individuen van eenen stam op de gebruikelijke wijze in het gebied van een andereu, maar beduidenden invloed hebben zij op hunne omgeving niet uitgeoefend.

De hierbedoelde onbebouwde gronden zijn alle door vaste grenzen aangewezen. Zoover zij langs de groote rivieren gelegen zijn, bestaan die uit beekjes, ravijnen, rotsen, groote steenen, reusachtige of bijzonder gevormde boomen en dergelijke. In 't binnenland worden meestal waterscheidingen als grenzen aangenomen, maar berg- of heuveltoppen, rotsen enz. dienen ook wel daartoe '. Deze

1 Ter verduidelijking volgen hier de grensomschrijvingen $1^{\mathrm{e}}$ der kampong Karingan an de Téwérivier tegenover het civiel etablissement en $2^{\circ}$ van het komplex Mangkiam, Bintangminggi, Moeara Boetoeng.

Ad I. Van Telok majang over de Saëng Boeng (Saëng = waterscheiding) naar Patoeng Besi (een reusachtige ijzerhoutboom) naar Oenoeö en afdalende naar de Sei Kimsoei. Van hier naar de monding der Sei Sikoei (linker zijrivier der Téwé), deze volgende tot hare bron op de Saëng Balang; van hier achtereenvolgens naar de bronnen der Seis Pauran en Maranim over het Djangan gebergte langs de Sei Inoeh naar Poensoeng Taboeijan en Sei Tanrahim en langs de Liti naar den linkeroever der Barito.

Aan den rechter Barito-oever van de plaats gelegen tegenover Telok majang noordwaarts naar de Sei Boekaoe en hare bron; daarna zuidwaarts naar de bronnen der Sei Mangaris en de Telok Balang in de Rapènrivier; eindelijk naar de bron der Sei Maté en deze afzakkende naar hare monding in de Barito.

Ad 2. Aan den linkeroever der Barito van den koesiboom, even ten noorden der kampong Boentok ketjil, recht oostwaarts tot de koesi Djarang, staande tusschen de bronnen der Seis Panran en Inoeh; vervolgens de Saëng Mansi tot de bronnen der Sei Taboeloeh en deze stroomaf tot hare monding.

Aan den rechteroever der Barito. De Sei Boeloe even ten zuiden der Lemo- 
grenzen kunnen echter door het bestuur niet worden gekontroleerd wegens de ontoegankelijkheid der binnenlanden en het totaal gemis aan kaarten. De eenig bestaande, door het topographisch bureau te Batavia samengesteld naar de opnamen van wijlen den kontroleur W. E. M. S. Aernout, zijn alle-- met uitzondering van een schetskaart van het distrikt Boven-Doesson - rivierkaarten van de Barito en détailkaarten van de voornaamste gedeelten harer zijrivieren ${ }^{1}$. Grensomschrijvingen, gegrift op lontar- of andere blâren, dan wel op metaal, heb ik nergens aangetroffen; zij worden eenvoudig in het geheugen der oudsten van het volk bewaard en mondeling aan het nageslacht overgeleverd. Gewoonlịk geschiedt dit eenmaal in de maand in tegenwoordigheid van alle ingezetenen, ook de jongeren. Dientengevolge geeft de grensbepaling van elk gebied hoogst zelden aanleiding tot moeilijkheden; en waar deze voorkomen worden zij gemakkelijk door het bestuur beeindigd, na belanghebbende hoofden en bevolking te hebben gehoord.

In de onderafdeeling Boentok bestaan geene vaste grenzen van de onbebouwde gronden, behoorende tot een kamponggebied. Het communaal bezit van den stam, het geslacht of de familie is daar overgegaan op het distrikt, d. i. de administratieve eenheid, hetgeen wel eens aanleiding geeft tot geschillen, vooral over het recht tot inzameling van boschprodukten en als gevolg daarvan het tiendrecht ${ }^{2}$.

rivier, van hare monding tot haren oorsprong, gelegen op het Moelanggebergte tusschen de bronnen der Seis Běnangin en Moelang (deze is een rechter zijrivier der Lemo) en van hier rechtuit naar de bronnen der Sei Pèmpèn op den berg Réwa en eindelijk, dit beekje volgende, tot zijne uitwatering in de Barito.

1 Deze kaarten zijn:

De Barito-rivier met haar linker zijrivier de Lahei, schaal 1:70000.

De Menawien, de Laoeng, beiden van Boven-Doesson, en de Mengkatibrivieren, schaal 1:100000.

De Téwé- en de Ajoe-hrivieren, schaal 1:20000.

De Montalat- en de Karaoe-rivieren, met de linker zijrivieren dezer laatste, de Toejaoe, de Pakoe en de Plantaoe, schaal 1:40000.

Verder heeft de heer Áernout nog eene kaart vervaardigd van den berg Boendang (distrikt Boven-Doesson), waarop het gelijknamig riviertje, zijtak der Laoeng, ontspringt. Die berg, een ware vesting, wordt door de Sultanspartij beschouwd als haar laatste bolwerk, waarheen de pretendent-sultan zou moeten wijken ingeval tegen hem eene militaire expeditie werd georganiseerd.

Ook deze kaart zal vermoedelijk bij het Topographisch bureau berusten.

1 Deze toestand, in strijd met de adat, is zeker vreemd bij eene bevolking met beschaafde, zeer ontwikkelde, zuiver dajaksche hoofden. Hij werd in 't leven geroepen door den kapitein waarnemend eiviel gezaghebber van Mara- 
Alle bewoners eener kampong, behoorende tot denzelfden stam, hebben dezelfde rechten op de onbebouwde gronden tot die kampong behoorende. Uitgezonderd begrafplaatsen, heilige offerplaatsen en zoogenaamde tanah pamali, kan iedereen een stuk grond ontginnen waar hij wil en daarop planten wat hij wil, maar hij is verplicht dien binnen zekeren.tijd te ontginnen, af hankelijk van de werkzaamheden der overige personen met wie hij samen een ladang aanlegt. Doet hij dat niet, dan vervalt zijn recht en kan een ander van die gronden gebruik maken, tenzij de eerste aantoont door omstandigheden van zijnen wil onafhankelijk, bijv.: ziekten van hem of zijn gezin, daarin te zijn verhinderd.

Kortom, hij mag met inachtneming der rechten van anderen en de hieronder te vermelden regelen, die gronden ontginnen, bebouwen, de daarop voorkomende produkten inzamelen en tot eigen gebruik aanwenden.

Formaliteiten worden bij dergelijke occupatie niet in acht genomen, dan alleen dat, indien iemand over een stuk onbebouwden grond zijner kampong weuscht te beschikken, hij daarvan aan het kamponghoofd kennis geeft met opgave van het doel, waartoe hij ze wil bezigen. Natuurlijk is dit altijd het beplanten met padi en andere voedingsgewassen.

Vooraf is hij verplicht merkteekens te stellen - tadjang geheeten - om de uitgestrektheid der gronden, die hij begeert, aan te wijzen, gewoonlijk bestaande uit omgekapte boomen, staken, steenen enz. Een onderzoek volgt, in hoever daarbij de verkregen rechten van anderen worden verkort, vooral of daartoe tanah berdatoe behooren. In de praktijk geschiedt dit doorgaans door den aanvrager zelf, omdat zijn belang medebrengt niet in moeilijkheden te

bahan, die op 17 Januari 1866 sub $N^{\circ} 52$ den schriftelijken last gaf „dat "de voortbrengselen van den grond komen ten bate van het distrikt, waartoe "hij behoort; dat niemand die zal mogen exploiteeren, dan met toestemming „der betrokken hoofden, die gehouden zijn te zorgen dat zich daaruit geene "moeilijkheden ontwikkelen en dat niemand zijne eigendommen zal mogen „reclameeren, tenzij hij binnen het jaar naar dat distrikt verhuist, waar zij "gelegen zijn."

Den $9^{\text {en }}$ Juli 1866 sehreeft de Resident aan dien zelfden wd. civiel gezaghebber: „Het bezit van zoogenaamde tinggirans of wasboomen stelt volgens "de bestaande adat onder den inlander in dit gewest een eigendomsrecht daar, „dat door geen vruchtgebruik van een aantal jaren valt te vervreemden enz. "Uit het vorenstaande zal UEdG. hebben ontwaard, dat geen bestaande adat "direkt mag worden verworpen." Toch bleef de last van bedoelden kapitein gehandhaafd, welke zoo diep in de adat greep. 
worden gewikkeld; want worden boomen, aanplantingen enz. door zijn schuld beschadigd of verwoest, dan is hij tot schadeloosstelling van den eigenaar verplicht. Staan er op het door hem gewenschte terrein nuttige boomen d.w. z. die deugdzame houtsoorten, hars, getah, tingkawan (boomvet) opleveren of andere gewassen zooals rottan enz., dan mag hij zich die toeeigenen.

$\mathrm{Zij}$ moeten daartoe vergunning vragen aan het hoofd der kampong, maar geweigerd mag die nooit worden.

Kosten zijn hieraan niet verbonden, maar gebruikelịk is het, dat men het kamponghoofd eenige kleine geschenken, doorgaans in vruchten, aanbiedt.

De ladangbouw, d.i. de rijstkultuur op droge, zooveel mogelijke maagdelijke gronden, regelt zich, evenals in de residentie Westerafdeeling van Borneo en andere gewesten van den Archipel, naar de Karangtika ${ }^{1}$ d. i. het sterrebeeld der Plejaden. Naargelang van zijuen stand boven den horizon is het de tijd om himba, baling-toewa, baling-moeda of bloekar te kappen en af te branden, terwijl het padiplanten moet zijn afgeloopen als dat sterrebeeld culmineert, op gevaar van misgewas. Ofschoon men niet verplicht is den afgestanen grond in gebruik te nemen, is het toch gewoonte, indien men niet daartoe overgaat, hem weer ter beschikking van het hoofd, d.w. z. van de bewoners der kampong te stellen, hetgeen altijd moet geschieden voordat de tijd van planten voorbij is. Die teruggave behoort echter tot de zeldzaamheden, omdat de voorloopige werkzaamheden zooveel mogelijk tegelijkertijd plaats vinden en iedereen dus daartoe reeds gronden uitgezocht heeft.

Zij kunnen die gronden niet braak laten liggen, maar moeten daaraan de kenbaar gemaakte bestemming geven, omdat anders de rechten van anderen worden verkort, hetgeen "pangorèh taoen" wordt genoemd. De gronden kunnen ook gebezigd worden voor weideplaatsen of andere doeleinden, maar aan eerstbedoelden is vooreerst geene behoefte, omdat er geen veestapel van eenige beteekenis bestaat. Daarentegen wordt nimmer genoeg padi verbouwd ter voorziening in eigen behoefte, zoodat ontginningen van grond uitsluitend aan de kultuur van voedingsgewassen worden dienstbaar gemakt.

De ontginner van een stuk onbebouwden grond verkrijgt door

1 Iets over de dajaksche sterrekunde. Mededeeling van S. H. Schaank, kontroleur van Pamangkat (Resid. Westerafdeeling van Borneo). 
die ontginning het recht om, met uitsluiting van ieder ander, die gronden te beplanten of tot eenig ander doeleinde te bezigen. De duur van dat recht hangt dus af van het doel, waartoe de gronden ontgonnen zijn. Zoo zal iemand, die een stuk onbebouwdeu grond met vruchtboomen heeft beplant, daarop zijne rechten kunnen doen gelden zoolang die boomen vruchtdragen en onderhouden worden; terwijl de rechten op de tot padivelden - ladangs ontgonnen gronden eerst dan verloren gaan, als zij weer tot den staat van woestheid zijn teruggekeerd. De eerste ontginner krijgt het erfelijk individueel bezitrecht op de door hem ontgonnen gronden, en kan die als zoodanig verpanden, wegschenken, verkoopen of verhuren.

Onbebouwde gronden, behoorende tot eene kampong, kunnen niet aan andere kampongs worden afgestaan omdat zulks zou gelijk staan met eene verandering van de grens en de daarmede gepaard gaande vermindering der bestaanmiddelen van de ingezetenen der kampongs, d.w. z. van den communalen rijkdom van den stam of de familie. Wel kan door het kamponghoofd, na raadpleging der oudsten, vergunning gegeven worden tot den afstand van gronden aan personen uit andere kampongs. Die afstand kan zijn definitief of tijdelijk. In het eerste geval, om er bijv. een kampong te vestigen, zooals te Djoedjoe, aan den linkeroever der Lahei-rivier, zijnde een enclave in het gebied der kampong Lahei I. Dan wordt eene overeenkomst gesloten met de hoofden en de oudsten, die het terrein aanwijzen voor de vestiging, met bijbehoorende begraaf- en offerplaats. Nadat de grenzen door vaste teekenen - of ijzerhouten palen zijn aangegeven, geschiedt de afstand, waarvan aan het bestuur wordt kennis gegeven.

Tijdelijk is die afstand, indien men in een ander kamponggebied ladangs verlangt aan te leggen of boschproducten in te zamelen, waartoe het verzoek nimmer wordt geweigerd. Men verkrijgt dan dezelfde gebruiksrechten op dien grond als de overige kampongbewoners, met dien verstande eveuwel, dat de grond, met al de daaropstaande boomen, gewassen en anplantingen tot de kampong terugkeert, indien men deze verlaat met het kennelijke doel nimmer daarin terug te keeren.

Dit laatste heeft voor tal van jaren plaats gehad met eenige lieden van het district Oost-Doesson, die zich metterwoon in Kampong Nihan, distrikt Midden-Doesson, hadden gevestigd, maar wier nageslacht naar het stamland terugkeerde. De vroegere eige- 
naren, noch hunne erfgenamen of rechtsverkrijgenden kunnen op dien grond ooit meer eenige rechten doen gelden.

Van de onderafdeeling Boentok, waar het communaal bezit van den stam is overgegaan op het distrikt, zooals wij gezien hebben, wordt gezegd dat onbebouwde gronden niet aan andere kampongs, maar wel an personen behoorende tot een vreemde kampong in hetzelfde distrikt ter ontginning kunnen worden gegeven.

De aanvrager voegt bij zijn mondeling gedaan verzoek om vergunning een geschenk aan het kamponghoofd, bestaande in een mandaoe, lans of geweer enz. In de onderafdeeling Boentok wordt niets betaald.

Geene bijzondere formaliteiten worden darbij in acht genomen, dan dat, waar zulks gebruikelijk is, het kamponghoofd mondeling toestemming verleent tot de gevraagde ontginning.

De voorwaarden, waaronder die afstand in den regel plaats heeft, zijn, tenzij anders wordt overeengekomen, dat de aanvrager in de

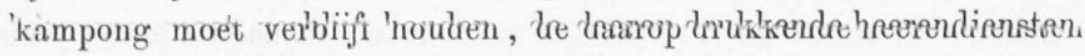
vervult, de belastingen betaalt, de gronden niet vervreemdt aan personen, niet behoorende tot denzelfden stam, tenzij met voorkennis en toestemming van het kamponghoofd, en dat de groud, met alles wat zich daarop bevindt, ook de vruchtboomen enz., zoodra hij dien verlaat, tot den gemeenschappelijken eigendom der kampong terugkeert.

Door een ontgonnen stuk grond te verlaten, tengevolge waarvan het geheel tot den staat van woestheid teruggekeerd is, verliest men daarop alle rechten. Dergelijke gronden komen dan weer ten bate van den communalen eigendom der kampong.

Als vreemdelingen worden beschouwd, afgescheiden van den godsdienst welken zij belijden, allen die niet tot denzelfden stam - in de onderafdeeling Boentok niet tot hetzelfde distrikt - behooren. Zij genieten dezelfde rechten tot ontginning der onbebouwde gronden als de bewoners der kampong zelf waar zij zich gevestigd hebben, mits zich onderwerpende aan de gebruikelijke of gestelde voorwaarden.

Die rechten bestaan daarin, dat zij al de produkten, welke de onbebouwde gronden opleveren, mogen inzamelen en die gronden zelve. tot eigen gebruik kunnen ontginnen. Zij mogen dus daarop jagen, visschen en allerhande boschprodukten inzamelen, zoomede ladangs en tuinen aanleggen, goud, steenkolen en andere mineralen graven, zoutbronnen exploiteeren enz.

De voorwaarden waaronder die rechten verkregen worden, bestaan 
in den regel hierin, dat zij zich in de kampong vestigen; gehoorzaamheid verschuldigd zijn an het inlandsche bestuur, i. c. het kamponghoofd; de belastingen betalen; de heerendiensten vervullen, en de gronden niet vervreemden, dan met voorkennis en toestemming van het kampongshoofd.

Door vestiging wordt niet alleen verstaan het wonen in de kampong, maar ook en vooral het huwelijk met een vrouw of meisje in de kampong, waardoor de kans ontstaat dat de stam niet in getalsterkte achteruit gaat. Met het oog hierop wordt wel eens de voorwaarde bij het huwelijk gemaakt, dat, bij het definitief verlaten der kampong, de moeder met de kinderen daarin zal achterblijven.

Dit geschiedde o. a. te Ipoeh, distrikt Midden-Doessoen met de vrouw en het kroost van een Chinees van Moeara Téwé, die naar Bandjarmasin terugkeerde.

In de kampong Lémo hebben zich eertijds kolonisten uit de Karaoestreek (distrikt Oost-Doesson) gevestigd, wier nazaten daar thans nog wonen en waaruit het bestuur der laatste tientallen jaren bij voorkeur de kamponghoofden koos.

Ik merk nog op, dat in deze afdeeling iemand door een lid eener kampong kan geadopteerd worden, waardoor hij dezelfde rechten verkrijgt als de overige kampongbewoners; dit middel wordt ook wel aangewend tot versterking van den stam.

Geene voorrechten, van welken aard ook, worden aan den eenen stand boven den anderen toegekend.

De vraag rijst thans, of de inlander eenig recht van beschikking over de onbebouwde gronden toekent aan ons Gouvernement.

Ter beantwoording van die vraag is het noodzakelijk - ook in verband, met hetgeen verder volgt - een overzicht te geven van de geschiedenis der hier besproken landen.

De Oost-Indische Compagnie beschouwde sedert 1787 het geheele Bandjarmasinsche rijk reeds als haar wettig eigendom, dat zij den Sultan bij wijze van leen had afgestaan om het voor haar te besturen. $\mathrm{Zij}$ beschouwde zich derhalve als souverein, maar de Sultan regeerde en behield zijnen invloed als meester van het gansche volk. De Resident daarentegen kon alleen in de nabijheid van onze forten zijn gezag doen gelden, dikwijls nog met veel moeite.

De lasten van het gewest overtroffen verre de baten en stegen gedurende het Engelsche tusschenbestuur - 1812 tot 1816 - dermate, dat zij 500.000 ropijnen hooger waren dan de ontvangsten. 
Zoo stonden de zaken toen op 3 Januari 1817 het Gouvernement een nieuw kontrakt sloot met Sultan Sleman Almat Tamid Alalah, waarin, tot goedmaking der uitgaven voor de door hem verlangde bescherming, bij art. 5 bepaald werd, dat Z. H. "in vollen eigendom en souvereiniteit" afstand deed o. m. van "de gezamenlijke dajaksche provinciën."

Onder deze benaming had de Sultan aan het Engelsche Gouvernement ook afgestaan o.m. de Doessonlanden, maar deze, diep in het binnenland liggende, hadden voor ons weinig waarde zonder een talrijk en kostbaar personeel, weshalve zijn verzoek om ze hem te laten, zeer gaarne werd ingewilligd, behoudens het recht van 't Gouvernement tot exploitatie der goud- en diamantmijnen en der bosschen.

Dit kontrakt werd op 13 September $18 \approx 3$ in dier voege gewijzigd dat de Sultan "in vollen eigendom" afstond "de Bekompai en Doesson" en in verband daarmede tevens vastgesteld dat die landen zullen worden geadministreerd gezamenlijk door het Gouvernement en den Sultan, die de inkomsten gelijkelijk zullen deelen; dat Z. H. zijn aandeel daarin als apanage zal schenken aan den tijdelijken rijksbestuurder, en dat de handel vrij zal zijn voor beider onderdanen, mits zich gedragende aan de bevelen, hun vanwege 't Gouvernement en den Sultan gegeven ten aanzien van hoofdgeld, tollen "of andere billijke inkomsten."

Deze onbestemde regeling gaf aanleiding om bij art. 4 van het kontrakt, dd. 4 Mei 1826 gesloten met den nieuw optredenden Sultan, den kroonprins panembahan Adam, - den afstand te bedingen van "het eiland Bekompai" enz. en "de landen algemeen bekend onder den naam van Doesson, waartoe behooren alle negorijen, welke aan den linker- en rechteroever der groote Doessonrivier gelegen zijn, beginnende van Mengkatib opwaarts tot aan de negorij Siang en vandaar benedenwaarts tot aan de monding der rivier van Marabahan." In verband met dien afstand werd tevens bepaald, dat het Gouvernement van de inkomsten der Doesson jaarlijks aan den Sultan zou uitkeeren 2 pikoel was, 100 tjerana's en 100 pagaijons, en dat de rijksbestuurder Pangeran Mangkoe Boemi Nata van het Gouvernement jaarlijks een inkomen van 12000 ropijen zou genieten, om zijn verlies der inkomsten van de Doesson en Bekompai te vergoeden. Bij kontrakt dd. 18 Maart 184.5 werden de grenzen van het geheele Gouvernementsgebied vastgesteld.

Het Gouvernement heeft dus nimmer het recht van souverein op deze 
afdeeling gehad maar wel van eigendom, verkregen niet door verovering, maar door substitutie. Geen afstand van grond in eigendom kon en mocht plaats hebben zonder vrijwillige toestemming en medewerking daartoe van de eigenaren i.c. de opperhoofden der dajaksche bevolking, maar deze heeft niet plaats gehad, althans blijkt daarvan niets. De vorsten van Bandjarmasin, d. w. z. de vreemde maleische indringers, hebben zich nooit ingelaten of bemoeid met het patriarchale bestuur der dajaksche hoofden.

Dezen oefenden een onbeperkten invloed over hunne onderhoorigen, en beschikten vrij over den grond, evenals dat heden ten dage nog het geval is met ons onderdistriktshoofd Toemenggoeng Batang, ten opzichte van den volksstam der Siangs, terwijl genen zich uitsluitend bepaalden tot het heffen van belastingen in geld en in arbeid, en zich absoluut onthielden van elke beschikking over de onbebouwde gronden.

Te dien aanzien werden belanghebbenden bijv. tot het aanleggen van ladangs, het kappen van hout uit de bosschen, het vervaardigen van sirappen, het inzamelen van boschprodukten enz., voorzien van een reispas, verwezen naar de hoofden, met aanbeveling zich verder met hen te verstaan. Dit noemen hoofden en bevolking thans nog "koewassa orang, tida koewassa tanah."

Dit recht, en geen ander, heeft dus het Gouvernement van Sultan Adam bij kontrakt overgenomen.

Het behoeft wel niet gezegd, dat de administratieve indeeling in distrikten toenmaals niet bestond, maar eerst in 't leven geroepen werd na den val van het Bandjarmasinsche vorstenhuis en de inlijving van het rijk bij het Nederlandsch-Indische grondgebied.

Toen werden in landstreken, waar geen opperhoofden meer bestonden, de familiehoofden van denzelfden stam zooveel mogelijk vereenigd, onder een algemeen hoofd met den titel van "Loerah" of "Eerste hoofd" welke titels later werden geconverteerd in die van distriktshoofd. Zij waren dus de ware volkshoofden, de patriarchen, aan wie - ieder wat betreft zijn gebied, - de beschikking over den grond toebehoorde.

Hield men bij den aanvang der grondlegging van ous direkt gezag streng vast aan het begrip van stamhoofd, zooals blijkt uit een der overwegingen van het besluit van den Resident van Soerakarta, Gouvernements-Commissaris voor de Zuider-en Ooster-afdeeling van Borneo. dd. 11 Juni $1860 \mathrm{n}^{\circ} 24$, waarin te lezen staat "behoudens evenwel die van de twee zuiver dajaksche distrikten $6^{\circ}$ Volgr. VIII. 
Sihang en Patai, welke met het oog op dezer geringen omvang en de noodzakelijkheid orn uit eene noodwendige eerbiediging der volksbegrippen, de hoofden voor die districten steeds te kiezen uit de geslachten, waarin het gezag erfelijk is" enz.; later kwam hierin verandering, toen de eerbiediging der volksbegrippen niet meer noodzakelijk werd geacht en de bezoldigde inlandsche hoofden moesten plaats maken voor inlandsche ambtenaren, wier positie niet meer erfelijk was in het geslacht.

De dajaksche kamponghoofden zijn dientengevolge de vertegenwoordigers geworden der geslachten en familieën, bij wie van oudsher de handhaving van het gewoonterecht, de adat, berustte. Zij zijn dus de ware volkshoofden gebleven en, ten aanzien der beschikking over den grond, in de plaats getreden der voormalige Eerste hoofden, Loerahs enz.

Hoewel sedert meer dan 70 jaren tot directe onderdanen van het Gouvernement verklaard, blijven hoofden en bevolking dit, evenals den uit de benedonstrokon komondon Maloier, besohouwen als een vreemden indringer, tegen wien zij onmachtig zijn zich te verzetten.

Evenmin als het den Maleier ooit vergund was zich hunne gronden zonder hunne toestemming toe te eigenen en in gebruik te nemen, mag het Gouvernement dat doen. Wil dit dus de vrije beschikking daarover verkrijgen, hetzij ten behoeve van zichzelf voor den aanleg van openbare werken, den bouw van versterkingen enz., hetzij ten behoeve van anderen, dan behoort het zich te wenden tot de hoofden der kampongs, tot wier gebied de verlangde goederen bebooren, om ze tegen eene vooraf te bepalen schadeloosstelling over te nemen.

In de onderafdeeling Boentok kent de inlander aan het Gouvernement, evenals aan iederen vreemdeling het recht toe om de onbebouwde gronden te ontginnen, maar niet om daarover te beschikken ten behoeve van anderen.

Wij hebben thans te onderzoeken, welke rechten de bewoners eener kampong kunnen doen gelden op de natuurlijke produkten, voorkomende op of in de gronden tot die kampong behoorende.

De leden van denzelfden stam - in de onderafdeeling Boentok, van hetzelfde distrikt - hebben het recht de natuurlijke produkten in te zanelen, voorkomende op de gronden, door den stam geoccupeerd of tot het distrikt behoorende, als getah, damar, rottan, was, honig 
enz. Dit wordt beroesaha genoemd in den engeren zin van het woord; in uitgebreider beteekenis wordt daaronder ook ondergrondsche exploitatie verstaan, zooals het graven voor goud, steenkolen enz.

De eerste vinder van een vogelnestgrot of een nuttigen boom, waaronder bij voorkeur wordt verstaan een met bijennesten, - ook wel wasboom geheeten - , heeft daarop een individueel bezitrecht, waarmede hij naar goedvinden kan handelen. Hij is echter verplicht van zijn vondst aan het kamponghoofd kennis te geven en, om zijn recht op zulk een boom te handhaven, den omtrek daarvan tot een afstand van $1 \frac{1}{2}$ à 2 vadem schoon te houden van onkruid.

In de onderafdeeling Boentok moeten ook de eigendomsrechten in acht genomen worden, welke sommige personen hebben verkregen door het maken of schoonhouden en bevaarbaar maken van kleine diep landwaarts loopende gegraven kauaaltjes - tatah's - en soengeis. Op grond van dat recht mag de eigenaar het één tiende eischen van alle natuurlijke produkten, welke binnen 's lands gezameld, langs die tatah's en soengeis afgevoerd worden. Dit eigendomsrecht is erfelijk, maar geeft wel eens aanleiding tot geschillen.

Tot die inzameling van natuurlijke produkten, waaronder begrepen het jagen in de bosschen, heeft iedereen buiten het gebied zijner kampong, de vergunning noodig van het kamponghoofd, maar geweigerd wordt die nooit.

Daarvoor wordt niets betaald, dan alleen aan den eigenaar der soengei of tatah bovenbedoeld, waarlangs de produkten worden afgevoerd.

Op den delfstoffelijken rijkdom van den grond hebben zij dezelfde rechten als voor de bovengrondsche exploitatie; maar voor het goudwasschen in de bedding der Baritorivier en het winnen van zout uit de brounen wordt geene vergunning vereischt.

Ondergrondsche ontginning door de dajaksche bevolking heeft niet plaats, zij heeft daarvan een afkeer.

Vreemdelingen mogen evenzeer de bedoelde natuurlijke produkten inzamelen, mits vergunning vragende aan het betrokken kamponghoofi. Deze wordt hun zeer zeldzaam geweigerd, maar daarvoor betalen zij de hassil, bedragende het één tiende van de opbrengst. Dit kan vooruit geschieden bij taxatie en heet dan "pamasokan", maar doorgaans na afloop der inzameling, dit heet "tjoekai."

Voor het jagen wordt de helft van de jacht afgestaan. Deze, 
zoowel als de hassil, worden betaald aan het kamponghoofd, tot gelijke verdeeling met zijne onderhoorigen. In de onderafdeeling Boentok krijgt het kamponghoofd, onverschillig of hij vreemdeling is of niet het $\frac{1}{3}$ van de opbrengst, en de overige bewoners het $\frac{2}{3}$ gedeelte. In de districten Midden- en Boven-Doesson ontvangt hij, vreemdeling zijnde, maar gehuwd in de kampong, niets van de hassil, maar wel zijne kinderen.

In vroegere jaren kende men volstrekt niet de waarde der ondergrondsche voortbrengselen; maar sedert de Maleiers, na de vestiging van een geregeld bestunr, deze afdeeling in grooten getale zijn binnengedrongen, om in het distrikt Midden-Doesson naar steenkglen te graven, heeft men de beteekenis daarvan leeren begrijpen en is men begonnen ook daarvan de hassil te heffen.

Zooals boven gezegd erkent de inlander niet het recht van het Nederlandsche gouvernement om over de onbebouwde gronden naar goedvinden te beschikken, dus evenmin het recht tot inzameling der daarop of daarin voorkomende natuurlijke produkten.

Thans overgaande tot de bespreking van het waterrecht, kunnen wij volstaan met de volgende opmerkingen.

In deze afdeeling worden geene rechten uitgeoefend op het water der bronnen, ontspringende op de onbebouwde gronden tot de eene of andere kampong behoorende.

De oevers der rivieren worden, zoolang het tegendeel niet blijkt, beschouwd als onbebouwde gronden.

Iedereen heeft een gelijk recht op het water der groote rivieren, d. w. z. om daarin naar hartelust te visschen, het tot eenig ander doel aan te wenden enz. Hiervan zijn natuurlijk de tatah, soengei berdatoe en danaoe berdatoe uitgezonderd.

In rivieren als Soengei Lemo, Soengei Piuré, Soengei Ajoeh enz. hebben de bewoners der nabijgelegen kampong het uitsluitende recht, voor gezamenlijke rekening daarin staketsels te plaatsen tot het vangen van visch.

Zoolang iemand op een ladang woont, heeft hij datzelfde recht ten aanzien van een in de nabijheid stroomend beekje en niemand mag daarin visschen langs zijne ladang.

Is iemand, ofschoon geen aan een beekje gelegen ladang bezittende, de eerste plaatser van een staketsel geweest, dan mag hij aan iedereen het visschen daarin verbieden over zekeren afstand, welke plaatselijk zeer verschilt. 
Omtrent het winnen van goud uit de rivierbedding zie bl. 211. Het zooeven vermelde is in hoofdzaak van toepassing op de meren, door die gronden geheel of gedeeltelijk ingesloten. Sommige meren behooren echter tot het communaal bezit eener kampong als: Danaoe Rendja en Danaoe Mangkap - beiden aan den rechteroever der Lahei-rivier - tot kampong Moeara Inoeh; Danoe Boetoeng — aan den rechter oever der Barito - tot kampong Moeara Boetoeng enz.

Omtrent het recht der vreemdelingen om daarin te visschen, geldt hetzelfde wat boven gezegd is ten anzien van het recht om produkten in te zamelen. De eigen kampongbewoners mogen echter daaruit elken dag zooveel visch halen als noodig voor eigen behoefte. In het droge jaargetijde worden deze danaoe's ten algemeene nutte der kampong afgevischt, waarbij men zich bij voorkeur bedient van de akar ketoebah als middel om de visch te bedwelmen. Daar de Dajaks minder ervaren zijn in de vischvangst en hare hulpmiddelen, wordt het recht tot het afvisschen dier danaoes dikwijls aan vreemdelingen gegund, gewoonlijk Maleiers, tegen afstand van het een-tiende der opbrengst.

Moerassen, aangeslibde en drooggevallen gronden worden als onbebouwde gronden beschouwd, weshalve ook de daarvoor geldende gebruiken van toepassing zijn; met dien verstande, dat de beide laatstgenoemde soorten van gronden ten bate komen des eigenaars van den oever, indien deze bebouwd is. Drooggemaakte gronden worden niet aangetroffen. In de moerassen mag iedereen naar genoegen visschen, behalve als zij geheel door bebouwde gronden zijn ingesloten, in welk geval alleen de eigenaars daarvan het recht daartoe hebben.

Het is aan vreemdelingen niet veroorloofd, in de kleine rivieren en beekjes te visschen, omdat doorgaans anderen reeds daarop rechten uitoefenen. Wel mogen zij dat doen in de Barito en zijne groote zijrivieren, als de Laoeng, de Lahei, de Téwé, de Karaoe, de Patai, de Mengkatib, e. a. Hiervan wordt voornamelijk door personen van Marabahan en Bandjarmasin gebruik gemaakt om in het vischrijke gedeelte der Barito, tusschen de kampongs Mengkatib en Bangga iloeng naar de zoo gewilde bijawang te visschen, waarvan de kuit, zoowel versch als gezouten en gedroogd, een belangrijk handelsartikel uitmaakt.

Daarvoor vragen zij vergunning aan het kamponghoofd tot wiens gebied dat gedeelte der rivier behoort, en betalen zij het tiende van de vangst. 
Daar de bevolking geene rechten uitoefent op de bronnen, ontspringende op de onbebouwde gronden, heeft iedere vreemdeling daarover de vrije beschikking, mits geen nadeel toebrengende aan de bezittingen van anderen.

Gelijk boven is aangetoond, kent de inlander aan het Gouvernement geene rechten toe tot beschikking over onbebouwde gronden. Maar dan rijst de vraag, of die beschikking, hetzij door de Regeering, hetzij door personen kan worden verkregen tegen billijke schadeloosstelling.

Om die vraag te beantwoorden, is het noodig vooraf een oogenblik stil te staan bij de hoofdbestaanmiddelen der dajaksche bevolking, namelijk: landbouw en handel te land, wordende de handel langs de rivieren uitsluitend gedreven door vreemdelingen, speciaal Maleiers.

De landbouw bestaat alleen in de kultuur van rijst op droge gronden (ladangs). Tusschen de padi worden allerhande voedingsgewassen geplant, als djagong, cassavesoorten, suikerriet, diverse moeskruiden om als toespijs te dienen enz. Sawahs zijn in deze afdeeling onbekend. Jaarlijks worden uitgestrekte perceelen boschgrond daaraan dienstbaar gemaakt en bij de zeer groote uitgestrektheid dezer afdeeling, in verband met de geringe dichtheid der bevolking, zijn daarvoor nog overvloedig gronden beschikbaar '.

1 De sterkte der bevolking bedroeg op ulto 1897:

\begin{tabular}{|c|c|c|c|c|c|}
\hline Distrikten. & & Mannen. & Vrouwen. & $\begin{array}{l}\text { Aantal } \\
\text { zielen. }\end{array}$ & $\begin{array}{l}\text { Weerbare } \\
\text { mannen. }\end{array}$ \\
\hline Midden-Doesson & . & . 4902 & 4886 & 9788 & 2568 \\
\hline Beneden-Doesson & . & . 2044 & 2120 & 4164 & 766 \\
\hline Oost-Doesson . & . & . 5811 & 6042 & 11853 & 2340 \\
\hline Mengkatib. . . & . & 839 & 1028 & 1867 & 343 \\
\hline
\end{tabular}

Hiervan komen voor de onderdistrikten in Midden-Doesson:

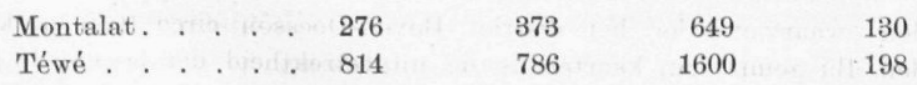

Het district Beven-Doesson is nog niet onder geregeld bestuur gebracht.

Eenigszins betrouwbare eijfers daaromtrent konden niet worden verkregen.

Naar hetgeen van hoofden, handelaren en andere daar bekende personen werd vernomen, moet de Boven-Doesson zwaar bevolkt zijn in evenredigheid van het overige dezer afdeeling. Deze berichten komen overeen met de rapporten van wijlen den kontroleur W. E. M. S. Aernout, die dat gebied in 
De rijstkultuur, aldus gedreven, levert doorgaans schrale oogsten, althans volstrekt niet in evenredigheid tot de gebezigde hoeveelheid plantpadi (bibit), zoodat jaarlijks groote hoeveelheden rijsst uit de benedenstreken worden aangevoerd om in de behoefte te voorzien $^{i}$.

De oorzaak daarvan ligt hoofdzakelijk in het feit, dat men het te bezwarend vindt te ver van de kampong maagdelijke boschgronden, geschikt voor de rijstkultuur, op te sporen en te ontginnen, terwijl de meer nabijgelegene uitgeput beginnen te raken.

In onmiddellijk verband met den landbouw staat de handel in boschproducten, waarvan de voorraden onuitputtelijk ziju. Wel is waar zijn er tegenwoordig groote nitgestrektheden waar bijv. alle kostbare getahboomen zijn uitgeroeid, maar overvloedig ontkiemen overal de jonge plantjes, zoodat het te verwachten is, dat na eenige tientallen van jaren de bodem weer daarmede bedekt zal zijn, ten minste als de boomen niet te jong gekapt worden om aan de steeds klimmende eischen van de Europeesche markt te voldoen.

$\mathrm{Bij}$ de onvoldoende padioogsten levert de inzamelende nijverheid een groote bron van inkomsten voor de bevolking, terwijl in het distrikt Boven-Doesson en in de streken aan der bovenloop der groote bevaarbare zijrivieren der Barito - waar overal groote schaarschte aan geld heerscht - hare voortbrengselen bovendien als ruilmiddel dienen ter verkrijging van rijst, zout, tabak, lijnwaden enz., welke artikelen haar door de slimme handelaren tegen

de jaren 1883-84 met zijne gewapende politiedienaren in alle richtingen, zoo te land als te water, doorkruist heeft.

In de laatste jaren heeft zich daarheen, vooral naar den uitersten bovenloop den Barito - aangelokt door de hooge, steeds stijgende prijzen van getah pertja en caoutchouc - een stroom van gelukzoekers gekeerd uit alle deelen van dit gewest om die handelsartikelen, waaromtrent de meest fabelachtige verhalen liepen, te winnen en af te voeren. Dientengevolge moet het bevolkingscijfer met circa 5000 vermeerderd zijn en thans ongeveer 16000 zielen bedragen.

De oppervlakte dezer afdeeling bedraagt ten naastenbij 1980 vierk. geogr. mijlen, waarvan voor het district Boven-Doesson circa 1030 vierk. geogr. mijlen. Bij gemis an kaarten is de uitgestrektheid der bebouwde gronden in deze afdeeling zelfs niet bij benadering te gissen, zooveel te minder dus in evengenoemd distrikt, waar alle contrôle, hoe gering of onbeduidend, ten eenenmale wordt gemist.

1 De padioogst bedroeg - uitgezonderd het district Boven-Doesson - in de jaren 1896 tot en met 1898 in pikoels resp. 6999, 6204 en 8339 of gemiddeld 7189 pikoel per jaar. 
het dubbele of het drievoud der waarde, dikwijls meer, handig worden opgedrongen en in rekening gebracht ${ }^{1}$.

Het is dus begrijpelijk dat de bevolking zeer ongaarne de grouden, waarvan hoofdzakelijk haar bestaan afhangt, voor altijd aan het Gouvernement dan wel aan particulieren afstaat, zelfs tegen een ruime schadeloosstelling in geld, tenzij voor haar tevens andere even rijk vloeiende bronnen van inkomsten wordęn geopend.

Zị gevoelt instinktmatig dat zij - bij het voortschrijden der Europeesche industrie en het toenemen van beschaving en ontwikke-

1 Het is niet van belang ontbloot, hier een overzicht te geven van den omzet der voornaamste handelsartikelen te Moeara Téwé gedurende de jaren $1896-98$.

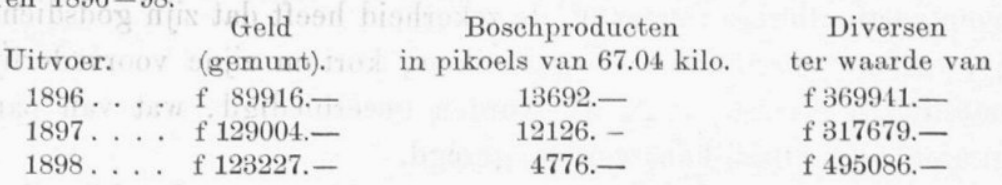

De voornaamste boschproducten waren:

\begin{tabular}{|c|c|c|c|c|}
\hline 1896. . & Rottan. & $\begin{array}{c}\text { Getahsoorten. } \\
\text { 8067.- }\end{array}$ & $\begin{array}{c}\text { Eetbare } \\
\text { vogelnestjes. } \\
6,13\end{array}$ & $\begin{array}{c}\text { Steenkolen. } \\
6031 \text { ton. }\end{array}$ \\
\hline 7. & . 7323 & 1615.- & 8,70 & 2784 \\
\hline 898. . & . 3833 & $1415 .-$ & 4,11 & 2324 \\
\hline
\end{tabular}

De uitvoer van rottan in 1896 geschiedde nog in bossen of "gěloengs".

$\begin{array}{rccccc} & \text { Geld } & \text { Rijst (gepeld) } & \text { Zout } & \text { Lijnwaden } & \text { Diversen } \\ \text { Invoer } & \text { (gemunt) } & \text { in kilo's. } & \text { in liters. } & \text { ter waarde van } & \text { ter waarde van } \\ 1896 & \text { f } 168891 .- & 1283854 .- & 54799.50 & \text { f } 107315 .- & \text { f } 191649 .- \\ 1897 & \text { f } 126755 .- & 4281702 .- & 248098.40 & \text { f } 182558 .- & \text { f } 268729 .- \\ 1898 & \text { f } 219809 .- & 1007171 .- & 137476.60 & \text { f } 124568 .- & \text { f } 299.150 .-\end{array}$

Het zout wordt te Boentok in het pakhuis verkocht per kojang en onderdeelen daarvan. Bovenstaande herleiding in liters geschiedde naar den maatstaf opgegeven in den Regeerings-almanak van 1900 bladz. 564, namelijk één kojang $=30$ pikoel $=2011$ Liter en één pikoel $=67$ Liter.

Zooals men ziet, waren de jaren 1897 en 1898 over het algemeen zeer gunstig voor den handel te Moeara Téwé. Dit was een gevolg van den ongekend hoogen waterstand in de Barito-rivier in 1897, welke geruimen tijd aanhield, zoodat men ruimschoots gelegenheid had alle opgestapelde voorraden af te voeren.

Zeer belemmerend voor den handel werkt de zoogenaamde "talian" d. i. het verbod, om gedurende eenigen tijd bepaalde plaatsen of streken te bezoeken. Het gaat uit van een of meer hoofden, en wordt bekend gemaakt door het ophangen op de verboden plaatsen van uitgeplozen jonge klapperblâren. Op overtreding van dit verbod zijn in Boven-Doesson zeer zware straffen gesteld.

Reeds bij art. 19 van het kontrakt dd. 4 Mei 1826 werd Sultan Adam de verplichting opgelegd de "talian" in zijn geheele rijk af te schaffen en tegen te gaan, maar niettemin bestaat zij nog, zij het dan wellicht niet in die mate als eertijds. 
ling - hare voorvaderlijke adats moet prijs geven, maar tot zoolang verlangt zij, dat indien de afgestane grond wordt verlaten, hij weer terugkeert tot de kampong, waartoe hij behoord heeft. Hieruit blijkt dus dat er geene onbebouwde gronden voorkomen, welke hijzelf niet noodig heeft.

Ditzelfde doet zich voor in de onderafdeeling Boentok. Daar erkent de inlander wel het recht van het Gouvernement om de onbebouwde gronden te ontginnen, even als iedere vreemdeling, maar niet om daarover te beschikken ten behoeve van anderen. Ten allen tijde zal dus het Gouvernement tot schadeloosstelling verplicht zijn.

Indien het tot een afstand kwam, zou de inlander in deze geheele afdeeling an het Gouvernement verre de voorkeur geven boven particulieren, omdat hij de zekerheid heeft dat zijn godsdienst, zijne zeden, gewoonten en gebruiken, kortom zijne voorvaderlijke instellingen zooveel mogelijk worden geeerbiedigd, wat van particulieren viet altijd kan worden gezegd.

In strijd met de in dit gewest en elders naar 't schijnt heerschende begrippen omtrent den kwaadaardigen inborst der Dajaks, zijn zij - zoover nog niet onder vreemde, voornamelijk maleische invloeden verbasterd of bedorven - een goed, zachtaardig, bescheiden en opgewekt volk. Vreemdelingen krijgen gemakkelijk een groot overwicht, vooral indien zij door bloed- of aanverwantschap met de Dajaks zijn verbonden.

Hoewel hunne zeden en gewoonten veel meer overeenkomen met die der Chineezen, die hen bovendien niet, gelijk de Maleiers, als heidenen, als onreinen verafschuwen, voelen de Dajaks zich toch meer aangetrokken tot de laatsten.

De redenen hiervan moeten m. i. voornamelijk gezocht worden in de twee hierna te vermelden omstandigheden. Het is den Chineezen nooit toegestaan zich in deze afdeeling te vestigen, tenzij tijdelijk in 't belang van 's lands verpachte middelen of leverantien; terwijl de Maleiers, zelfs de voor ons gezag gevaarlijkste individuen, zich overal, ook in het distrikt Boven-Doesson, vrij mogen bewegen. Hiervan maken zij een ruim gebruik om de Chineezen - vaak hunne handelsconcurrenten - , waar zij zich vertoonen in discrediet te brengen. De vertegenwoordigers van beide rassen hebben dus nimmer gelegenheid gehad elkaar genoegzaam te leeren kennen om met elkaar te kunnen harmonieeren, evenals dat het geval is in het rijk Sambas der westerafdeeling van Borneo.

Zoowel Chineezen als Dajaks zijn zeer gehecht aan hunnen stam 
en beide rassen beoogen steeds een versterking daarvan; maar juist daarom verdragen zij elkander niet. Aangezien nu van den afstand van grond aan Chineezen hunne vermenging met de dochteren des lands verwacht wordt, kan de Dajaksche bevolking daarvan niet anders dan de nadeelige gevolgen voor haren stam vreezen, en makt zij ernstige bedenkingen om onder particulieren ook Chineezen te begrijpen. In de onderafdeeling Boentok bestaan die bezwaren naar men zegt echter niet.

Daar hoofden en bevolking tegenover vreemdelingen hunne minderheid voelen, vooral in de distrikten Midden- en Boven-Doesson en de eersten hun gezag tegenover hen niet weten te eerbiedigen, rekenen zij, bij de vestiging van particulieren, vast op de hulp en den steun van het Europeesche bestuur.

Andere vreemdelingen, bijv. Klingaleezen, Arabieren enz. komen in deze afdeeling niet voor.

Over het algemeen bestaat er weinig vooruitzicht, dat bij het in exploitatie brengen op eenigszins groote schaal van onbebouwde gronden in den omtrek daarvan voldoend werkvolk zal kunnen verkregen worden.

De Dajaks zijn niet lui, maar niet gewend aan geregelden arbeid ${ }^{1}$. Dit laatste geldt evenzeer van de Maleiers, maar zij zijn lui bovendien. Zij houden zich bij voorkeur bezig met het zooveel gemakkelijker handeldrijven met woekerwinsten; om den landbouw bekommeren zij zich niet dan noodgedwongen.

Liever dan met vast werk een ftink daggeld te verdienen, verkiezen Dajaks en Maleiers beide het naar onze begrippen ongebonden leven in bosch of kampong.

Aanleiding voor eene andere levenswijze bestaat er voor hen niet; de uitgestrekte wildernissen voorzien direkt of indirekt ruimschoots in hunue behoeften. Tegen den aanvoer van vreemd werkvolk zouden bij de bevolking of hare hoofden geene bezwareu bestaan, mits dat vreemde werkvolk zich behoorlijk gedraagt, de vrouwen en huwbare dochters met rust laat, zich niet tegen de zeden en gewoonten vergrijpt en mits de belangen der oorspronkelijke bewoners voldoende tegenover dat werkvolk worden behartigd.

1 De heer Liddelow van de concessie Sambas goldmines - in 1889 ingebracht in de naamlooze vennootschap West-Borneo-goud-maatschappij te Amsterdam - werkt te Boedok bij voorkeur met dajaksch werkvolk, dat, eenmaal behoorlijk geoefend, volstrekt geene moeilijkheden maakt, integendeel rustig en arbeidzaam is. 
Thans doet zich eene zeer belangrijke vraag voor:

Zou de veiligheid der personen en goederen van de ondernemers, die zich op de onbebouwde gronden wenschen te vestigen, overal genoegzaam gewaarborgd kunnen worden?

Om hierop een antwoord te kunnen geven, is het noodig den toestand na te gaan van het distrikt Boven-Doesson, omdat daarvan de rust en de welvart in deze geheele afdeeling, ja zelfs in zekere mate die in het geheele gewest afhangt.

Sedert de expeditie van 1859 houden zich daar op:

$1^{\circ}$. De pretendent-Sultan, goesti Mohamad Sĕman kortweg goesti Matsĕman genoemd.

$2^{\circ}$. De eenig overgẹbleven zoon van wijlen Soerapati, met name Toemenggoeng Djidan, alias Radhěn Depati Mangkoe Negara.

$3^{\circ}$. Goesti Mohamad Arsat, zoon van wijlen Pangeran Matsaït en schoonzoon des pretendents.

$4^{\circ}$. Mohamad Napis, alias Pangeran Mangkoe Boemi.

$5^{\circ}$. Pangeran Bandjarmas, zoon des pretendents.

$6^{\circ}$. Tal van andere vorstentelgen van lageren ${ }^{-}$rang en minderen invloed dan de evengenoemden.

Nooit hebben wij ons veel met dat district ingelaten; maar onze vroeger reeds geringe bemoeienis werd wel tot een minimnın beperkt toen, nu 15 à 16 jaar geleden, als beginsel werd aangenomen het geheel aan zich-zelf over te laten '. Zoodra de sultanspartij de zekerheid had dat men haar ongemoeid liet, pleegde zij voorloopig van haar zijde geen daden van vijandelijkheid, maar van den anderen kant heeft zij ook nooit ernstig aan onderwerping gedacht. In werkelijkheid bleef de controleur te Boentok ten opzichte van het voornaamste deel zijner onderafdeeling geheel afhankelijk van het hoogst onbetrouwbaar districtshoofd Dakoeb, alias Radhen Djaja Kasoema, die voortdurend met den vijand heulde; het district Boven-Joesson, een uitgestrekt en vruchtbaar Jandschap, bleef overgegeven aan de sultanspartij, - m. i. zeer ten nadeele der toch gewenschte pacificatie.

Doch zoo wellicht voor genoemd beginsel destijds aannemelijke redenen waren aan te voeren, - moeilijk is daarmede te rijmen de aanstelling, een paar jaar later (Ind. Stbl. $1886 \mathrm{n}^{\circ} 227$ ) van drie bezoldigde districtshoofden in de Boven-Doesson; daarvan was be-

1 Zie o. a. Het Nieuws van den Dag van 16 Februari $1900,2^{\circ}$ blad, waar ook vermeld staat dat de Gouverneur-Generaal van Rees den last verstrekte „om den Pretendent-Sultan in de Boven-Doesson met rust te laten." 
zwaarlijk eenig nut te verwachten, gelijk beneden nog nader zal blijken.

De politieke toestand is dan ook jaren lang hoogst ongunstig gebleven.

Veel verbetering kwam daarin tijdelijk na mijne ontmoeting, den $17^{\mathrm{n}}$ Juni 1897 , met den bovengenoemden Toemenggoeng Djidan; de eerste ontmoeting van hem met een bestuursambtenaar! Doch het wantrouwen bleef bestaan, en de pretendent ontzag zich niet, het bestuur te misleiden, ondanks de heiligste beloften die hij schriftelijk had gedaan.

Wellicht had dat wantrouwen gaandeweg kunnen verdwijnen, wanneer niet de komst te Moeara Teweh van den resident per stoomer Barito, op 5 September 1897, vergezeld van den luitenant-kolonel, gewestelijk militaire commandant en 25 Europeesche soldaten, daaraan grootelijks voedsel gegeven had. Die komst, niet door mij uitgelokt, veroorzaakte eene algemeene opschudding, - vooral toen in de Boven-Doesson, uit de naaste omgeving vau den resident, liet gerucht verspreid werd dat er meer troepen zouden komen en dat dan tegen de sultanspartij zou worden geageerd.

Sedert was natuurlijk elke poging tot pacificatie van het district vruchteloos, en de toestand moeielijker dan ooit.

De pretendent-Sultan en zijn aanhang blijven gevaarlijke elementen ; zij verdienen niet het minste vertrouwen, en het is wel noodig dat op hunne handelingen nauwlettend wordt toegezien.

Ook de sociale toestand laat in dat distrikt nog uitermate veel te wenschen over. Hadden vóór het jaar 1884 reeds tal van onverlaten uit dit geheele gewest zich bij de sultanspartij geschaard, na dien tijd, - toen wij in hun oog groote zwakheid betoond hadden en ons niet meer met de Boven-Doesson schenen te durven bemoeien was dat distrikt, meer dan vroeger, een veilige schuilplaats voor allen, die geen genoegen konden of wilden nemen met de steeds toenemende betere toestanden, zoowel in deze afdeeling als in de benedenlanden, namelijk legitimisten, fanatieken, woelgeesten, ontevredenen, gevluchte misdadigers, bankroetiers en dergelijke individuen.

De handelaren, wel verre van een eerlijken handel te drijven, vinden daar een overschoone gelegenheid tot uitoefening van hun bedrijf middels allerlei ongeoorloofde, onwettige en misdadige handelingen, ten koste vooruamelijk der oorspronkelijke bevolking.

De vorstentelgen en het door hen ingestelde bestuur, personen door hen met weidsche titels begiftigd, vrouwen van eenigen rang 
of aanzien, allen matigen zich gezag aan en ondermijnen dat der door ons aangestelde of ons goedgezinde hoofden. Een grenzenlooze verwarring en willekeur heerschen er, nog bevorderd door het ongestraft blijven van misdaden en het voortbestaan der verderfelijke adat siang-moeroeng.

Onze bezoldigde distriktshoofden, verstoken van den steun van het Europeesche bestuur; verstoken van de middelen om hun gezag te doen eerbiedigen; verstoken van alle kontrole van den afdeelingschef, stonden en staan nog machteloos daartegenover, en schikken zich in hunnen tweeslachtigen toestand zoo goed mogelijk, natuurlijk ten koste van het Gouvernement.

Op den thans gevolgden weg blijft het distrikt Boven-Doesson een lastpost, nit een financieel zoowel als uit een politiek oogpunt, en moeten de traktementen der distriktshoofden beschouwd worden als weggeworpen geld ${ }^{1}$.

Deze politieke en sociale toestanden zijn wel innig, maar daarom nog niet onafscheidelijk aan elkaar verbonden. Wel oefenen zij op elkaar een overwegenden invloed, welke niet gering te achten is, maar elk afzonderlijk kunnen zij de grootste moeilijkheden aan eenen concessionaris veroorzaken.

Men vergete niet, dat de sultanspartij, allen die ons bestuur ongenegen of vijandig zijn en zij die voordeel trekken uit de bovenomschreven verwarde toestanden, de vestiging eener Europeesche industrie in hunne nabijheid met leede oogen anschouwen. Ook moet in het oog gehouden worden, dat Europeesche ondernemingen in deze afdeeling voor hoofden en bevolking geheel nieuw zijn; waarmede zij nog ten eenenmale onbekend, waarvoor zij bevreesd zijn en een afschuw hebben; ja zelfs dat de omgang met andere Europeanen dan de besturende ambtenaren, hun ten eenenmale vreemd is en zij dien moeten leeren, zoo niet onder den invloed, althans in de onmiddellijke nabijheid van individuen van wie te dien aanzien weinig goeds te verwachten is.

Het bovenstaande geldt speciaal het distrikt Midden-Doesson,

1 Volgens de reorganisatie van het gewest (Stbl. 1898, $\mathrm{n}^{\circ}$ 178) bedragen de traktementen der distriktshoofden f 2880. - 's jaars, terwijl de belastingen, (hoofdgeld in het geheele distrikt en vertiening in de streken beneden de distrikshoofdplaats Moeara Laoeng) in 1898 totaal bedroegen ruim $\mathrm{f}$ 1959.Gedurende mijne ontmoeting met Toemenggoeng Djidan vernam ik o. m. van hem, dat niet de helft de bevolking in de hoofdelijke belasting was aangeslagen en verresveg de meerderheid slechts f 0.05 tot $f 0.25$ per persoon opbracht in plaats van f 1.--, als bepaald bij art. 5 van Stbl. $1871 \mathrm{n}^{\circ} 301$. 
minder de ten zuiden daarvan gelegen distrikten Beneden-Doesson, Oost-Doesson en Mengkatib. Daar staan aan het hoofd trouwe, beproefde onderdanen van het Gouvernement; daar is initsdien de invloed van de sultanspartij en hare aanhangers en kwaadwilligen onbeduidend, daar zijn de mindere hoofden en bevolking meer gewend aan den omgang van andere Europeanen als de besturende ambtenaren; daar is dus de veiligheid van personen en goederen beter gewaarborgd.

Dit beteekent niet, dat men in die distrikten of elders in de benedenstreken van dit gewest, absoluut veilig is voor de beide bedoelde invloeden. De jongste treurige gebeurtenissen te Kendangan op 25 September 1899 (zie Javasche Courant van 6 October $1899 \mathrm{n}^{\circ}$ 80) leeren ons dat zij zich, evenals in vroegere jaren, thans nog zelfs ginds kunnen doen gevoelen.

De invloed, welke van de sultanspartij en haren aanhang, en van den socialen toestand in Boven-Doesson uitgaat, is en blijft voor dit gewest in 't algemeen en deze afdeeling in 't bijzonder hoogst verderfelijk. Het wordt dus dringend noodig, dat de pacificatie van dat distrikt, waarnaar sedert 1860 vruchteloos is gestreefd, ernstig wordt ter hand genomen en men zich er niet van afmaakt, gelijk wel eens geschiedde, met het vergelijken der positie van den besturenden ambtenaar te Moeara Téwé met die van wijlen generaal Gordon te Karthoem !

Daartoe is in de eerste plaats noodig, loslating van het bovenbesproken beginsel van niet-bemoeienis, ten einde steun te verschaffen aan onze distriktshoofden en aanrakingen te verkrijgen en te behouden met de mindere hoofden en bevolking; kortom om onzen invloedssfeer uit te breiden.

Alleen dan zal er mettertijd sprake kunnen zijn van openstelling van dat zoo rijke en vruchtbare landschap voor de Europeesche industrie; thans is de veiligheid der personen en goederen van de ondernemers, die zich op de onbebouwde gronden willen vestigen, in de eerste plaats in het distrikt Midden-Doesson, niet genoegzaam gewaarborgd.

De aanwezigheid in Boven-Doesson der afstammelingeu van het oude Bandjarmasinsche vorstenhuis, in de eerste plaats Goesti Mohamed Sěman en zijn energieken, zeer ontwikkelden schoonzoon Goesti Mohamed Arsat, kortweg Goesti Arsat genoemd - met wien ik tweemalen eene langdurige conferentie had - is een sineulend vuur, dat telkens opflikkert en onder gunstige omstandigheden. in een onbewaakt oogenblik, hier of daar in lichte laaie kan uitslaan. 


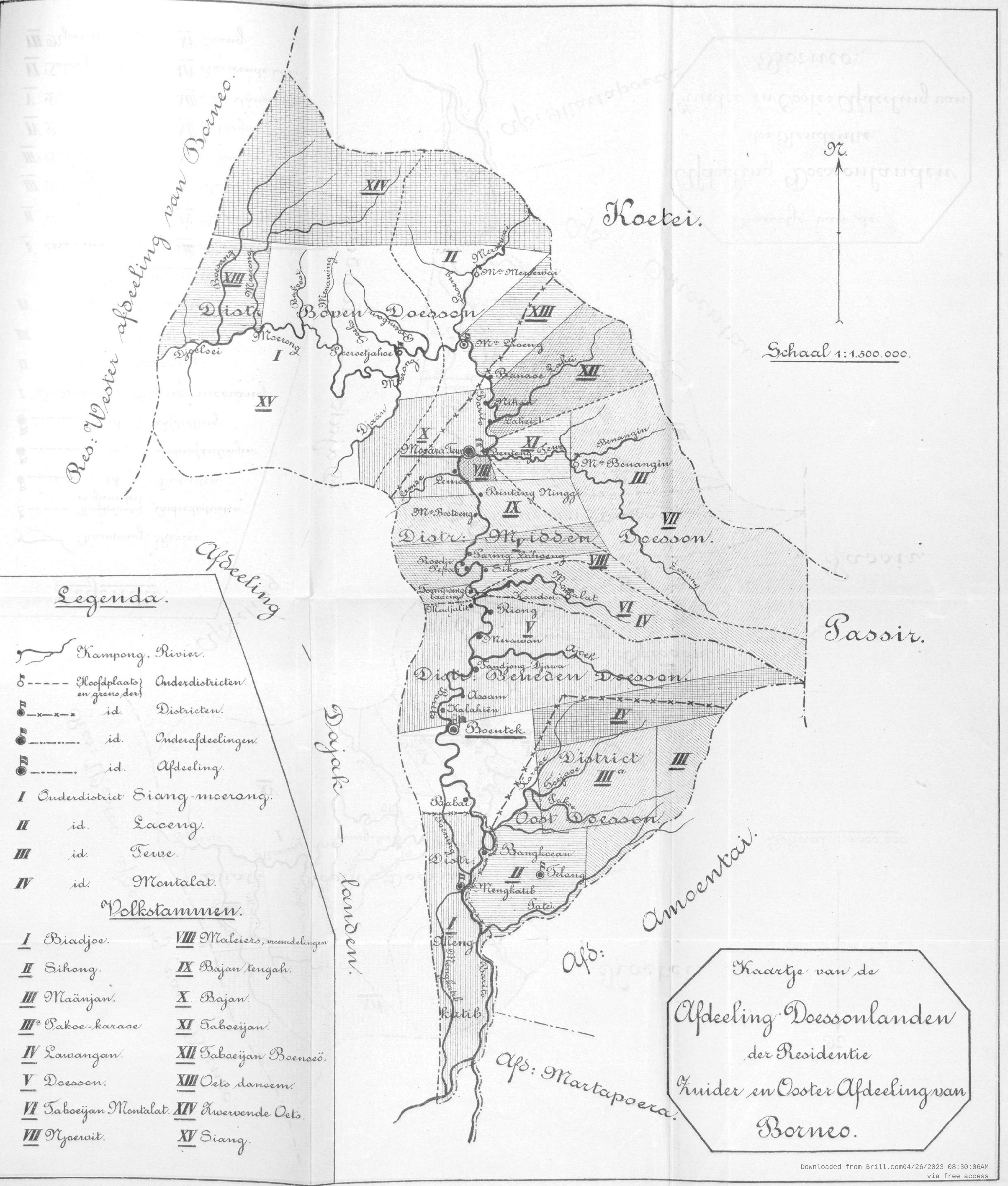

